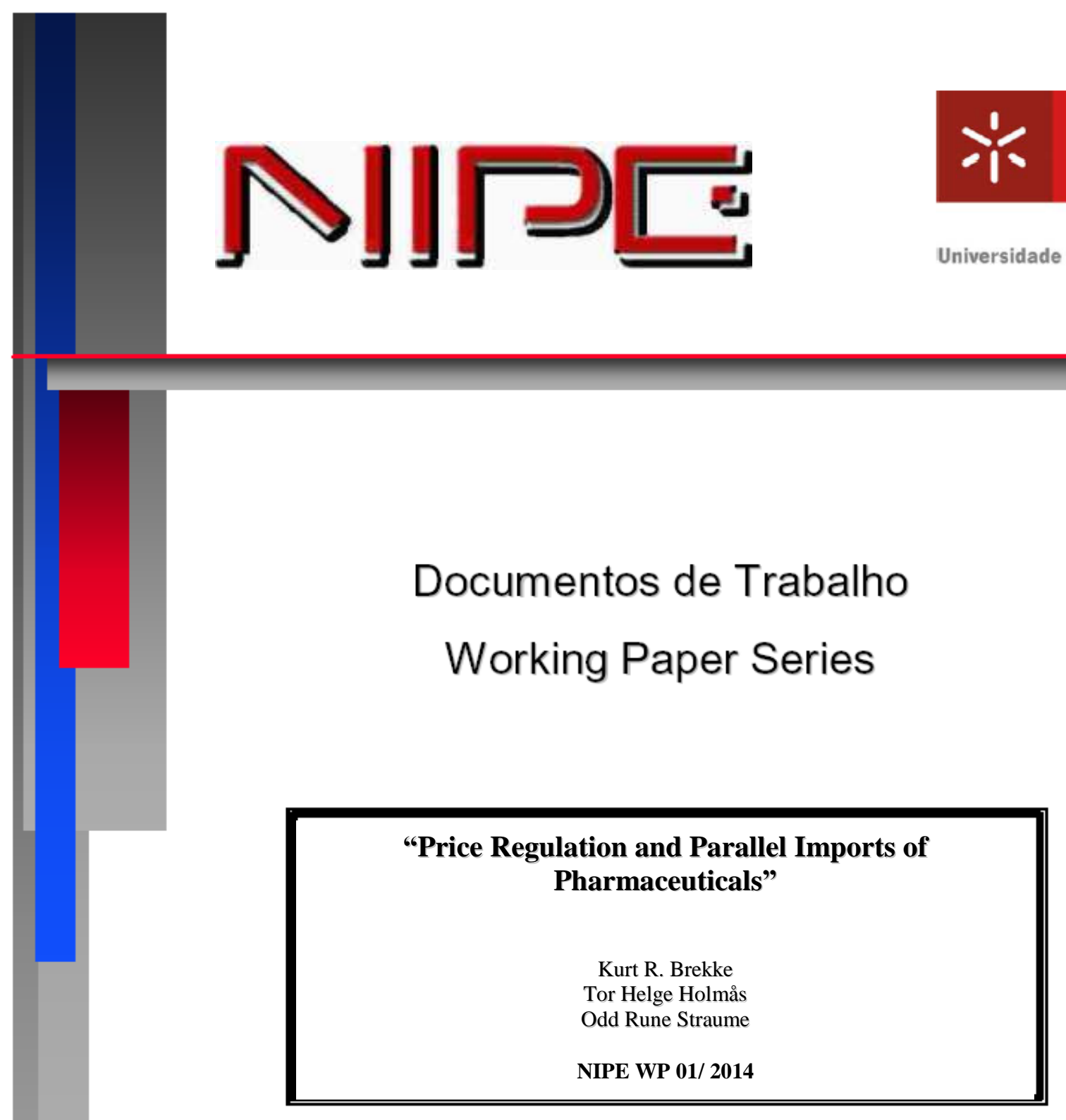

NÚCLEO DE INVESTIGAÇÃO EM POLÍTICAS ECONÓMICAS UNIVERSIDADE DO MINHO 


\section{"Price Regulation and Parallel Imports of Pharmaceuticals"}

Kurt R. Brekke

Tor Helge Holmås

Odd Rune Straume

NIPE ${ }^{*}$ WP 01/ 2014

URL:

http://www.eeg.uminho.pt/economia/nipe
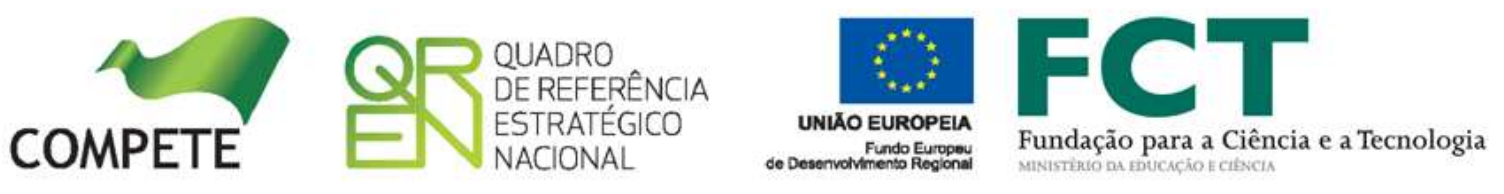


\title{
Price Regulation and Parallel Imports of Pharmaceuticals*
}

\author{
Kurt R. Brekke $\quad$ Tor Helge Holmås $\ddagger^{\ddagger} \quad$ Odd Rune Straume ${ }^{\S}$
}

January 2014

\begin{abstract}
This paper studies the effects of price regulation and parallel imports in the onpatent pharmaceutical market. First, we develop a theory model in which a pharmacy negotiates producer prices with a brand-name firm and then sets retail prices. We show that the effects of price regulation crucially depend on whether the producer faces competition from parallel imports. While parallel imports improve the bargaining position of the pharmacy, price regulation counteracts this effect and may even be profitable for the producer. Second, we use a unique dataset with information on sales and prices at both producer and retail level for 165 substances over four years (2004-7). Exploiting exogenous variation in the regulated price caps, we show that stricter price regulation reduces competition from parallel imports. While the effect is clearly negative on producer profits for substances without parallel imports, the effect is not significant for substances with parallel imports. Finally, we show that stricter price regulation reduces total expenditures, but the effect is much stronger for substances with parallel import. Thus, our results suggest that price regulation may promote both static and dynamic efficiency in the presence of parallel imports.
\end{abstract}

Keywords: Pharmaceutical market; Price regulation; Parallel imports

JEL Classifications: I11; I18; L13; L51; L65

${ }^{*}$ The paper has benefited from being presented at the Peder Sather workshop on Health and IO at UC Berkeley, November 2013. We are also grateful for comments by Christopher Whaley.

${ }^{\dagger}$ Corresponding author. Department of Economics, Norwegian School of Economics (NHH), Helleveien 30, N-5045 Bergen, Norway. E-mail: kurt.brekke@nhh.no.

‡Uni Rokkan Centre, Nygårdsgaten 5, N-5015 Bergen, Norway; and Health Economics Bergen (HEB). E-mail: tor.holmas@uni.no.

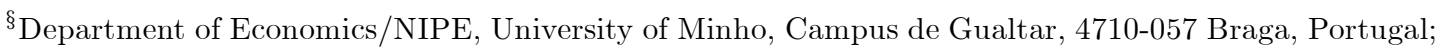
and Department of Economics, University of Bergen, Norway. E-mail: o.r.straume@eeg.uminho.pt. 


\section{Introduction}

In this paper we study the effects of price regulation and parallel imports in the pharmaceutical market for substances that are under patent protection. The presence of health insurance makes demand for pharmaceuticals fairly price inelastic. Combined with market power on the supply side, free pricing of pharmaceuticals is likely to result in rather high prices. Most countries therefore control pharmaceutical prices in order to contain medical expenditures. Such regulation is perceived to improve static efficiency by forcing prices closer to marginal production costs, but is likely to be harmful to dynamic efficiency since it reduces the returns on pharmaceutical firms' R\&D investments. ${ }^{1}$

Parallel trade of pharmaceuticals is also controversial for the same reasons. Allowing for parallel trade is likely to trigger (intra-brand) competition between the original producer and parallel traders in the importing (high-price) countries. This limits the scope for pharmaceutical companies to engage in international price discrimination and may contribute to price convergence across (high- and low-income) countries. ${ }^{2}$ Therefore, parallel trade may be good for static efficiency by stimulating competition, but bad for dynamic efficiency by reducing the pharmaceutical firms' patent rent.

In Europe price regulation and parallel trade are essential features of pharmaceutical markets. Almost every European country regulate pharmaceutical prices in order to control their medical expenditures. Parallel trade across member states is encouraged by the EU commission. The principle of free movements of goods implies that firms (or individuals) legally can trade pharmaceuticals without the consent from the original producer across national borders within the European Economic Area (EEA). In the US both price regulation and parallel trade (particularly from Canada) have been discussed as policy measures to better control the increasing medical expenditures, but has so far not been implemented mainly due to the concern about lower patent rent and thus incentives for

\footnotetext{
${ }^{1}$ This argument is well explained in Danzon (1997), and has received support from some recent empirical studies; see e.g., Giaccotto et. al. (2005), Vernon (2005), and Golec and Vernon (2006). Moreover, Kyle (2007) finds that strict price control may also deter or delay launch of new drugs, and therefore reduces the availability of drugs within a given country.

${ }^{2}$ One important reason why parallel imports arise is to arbitrage away international price discrimination, which is widely observed for pharmaceutical products (e.g., Ganslandt and Maskus, 2004). However, Kyle (2010) finds that pharmaceutical producers may still be able to maintain differential pricing across countries by using non-price strategies (e.g., packaging) to limit the scope for parallel trade.
} 
innovation.

Despite being very different policy instruments, parallel trade and price regulation are likely to have similar effects on market outcomes and welfare, and one may conclude that the combination of these two instruments is particularly bad for the pharmaceutical firms. In this paper we will show that these conjectures are actually false, and that the interaction between price regulation and parallel imports really changes the expected effects. In particular, we will show that stricter price regulation may in fact be beneficial to the pharmaceutical firms in the presence of parallel import, though it is clearly negative in absence of parallel imports.

Our paper consists of both a theory and an empirical part. In the theory part we consider a patent-protected brand-name drug that is sold in a domestic (high-price) and foreign (low-price) country. In the domestic country, the drug is distributed by a monopoly pharmacy, and the producer price is a result of (Nash) bargaining between the brandname producer and the pharmacy. The pharmacy can also buy a parallel-imported drug version and sell this in competition with the original drug. The market for parallel trade is competitive, and the profitability of parallel import is determined by the producer price difference between the domestic and foreign country. ${ }^{3}$ The pharmacy sets the retail prices of the original and parallel-imported drugs in the domestic country subject to price cap regulation, which in equilibrium is binding for the original product, but not for the parallel-imported product.

We study the effects of price cap regulation both with and without parallel imports. In absence of parallel import, we show that a lower price cap always reduces the bargained producer price, and is harmful to both producer and pharmacy profits. However, in presence of parallel import, the effects of stricter price cap regulation on producer price, sales and profits are ambiguous. If the original producer's (pharmacy's) bargaining power is sufficiently high, then a lower price cap increases (reduces) producer prices. Moreover, if the producer price increases due to stricter price cap regulation, then the original producer

\footnotetext{
${ }^{3}$ Very few papers make the distinction between producer and retail prices when studying parallel trade. One exception is Chen and Maskus (2005), building on Maskus and Chen (2004), who make this point and argue that parallel trade occurs partly because of differences in the vertical pricing structure across countries.
} 
also obtains higher profits. Otherwise, the effect on the original producer's profits is ambiguous.

The reason for the qualitatively different results is that competition from parallel import changes the original producer's incentives. If the original producer pushes for higher prices, the pharmacy will respond by reducing the retail price of the parallel-imported drug in order to shift demand away from the (less profitable) original drug towards the (more profitable) parallel-imported drug. The bargained producer price is therefore constrained not only by relative bargaining power, but also by the producer's incentive to restrain competition from parallel importers. Thus, competition from parallel importers shifts market power from the upstream to the downstream part of the industry, improving the bargaining position of the pharmacy vis-à-vis the producer. However, stricter price cap regulation tends to weaken competition from parallel importers, shifting market power back towards the upstream part of the industry. The original producer can take advantage of this and obtain a higher producer price, if his relative bargaining power is sufficiently strong. This explains why the original producer may benefit from a stricter price cap when facing competition from parallel import.

Based on the theoretical analysis, we derive the following predictions for empirical testing: (i) in markets with parallel imports, a reduction in the price cap leads to an increase in both sales and market share of the original drug; (ii) in markets without parallel imports, a lower price cap reduces both the producer price and the profits of the brand-name producer, whereas in markets with parallel imports both these effects are smaller and might even be positive. We also test the effect of stricter price cap regulation on total drug expenditures, although our analysis shows that the effect is theoretically ambiguous.

To test these predictions, we make use of a unique administrative data set with detailed information on all prescription-bound sales in Norway. ${ }^{4}$ Our sample consists of 165 on-patent substances and contains monthly information about sales and prices at both producer and retail level (for each product) over a four-year period from 2004 to

\footnotetext{
${ }^{4}$ Actually, we merge data from two administrative databases from the Norwegian Institute of Public Health; the Prescription database and the Wholesale database. More details are provided in Section 5.
} 
2007. The data set also includes information about the retail price cap and whether or not the product is parallel-imported. The descriptive statistics reveal that (i) 55 of the 165 substances have sales of parallel-imported products during the sample period, (ii) the parallel-imported drugs are on average priced lower than the original drug at both producer and retail level, (iii) the retail price cap tends to be binding for the original drug, and (iv) the pharmacy profit margins are fairly high for both drug versions, but slightly higher for the parallel-imported drugs.

When testing the empirical predictions, we exploit exogenous variation in the price caps. Since the price cap is determined by foreign prices and exchange rates, this enables us to identify causal effects of changes in the price cap regulation on the dependent variables. We use a regression model with product (substance) fixed effects, which control for unobserved (and observed) variation that is constant over time (e.g., product characteristics) and period fixed effects that control for time trends. Consistent with our first prediction, we find that stricter price cap regulation reduces competition from parallel imports resulting in higher market shares and sales of the original brand-name product. Dividing our sample into substances with and without parallel import, we find, consistent with our second prediction, that stricter price cap regulation reduces producer prices, but the effect is substantially weaker for substances with parallel imports. Moreover, we find that a lower price cap has a strong, negative effect on the original producers' profits for substances without parallel imports, but has no significant effect on the original producers' profits for substances with parallel imports. Finally, we find that stricter price cap regulation reduces total expenditures, but the effect is much stronger for substances with parallel imports than for substances without parallel imports.

The rest of the paper is organised as follows. In the next section we give a relatively brief overview of some related literature and explain the contribution of our paper. In Section 3 we provide a brief description of the Norwegian pharmaceutical market. In Section 4 we present our theory model and derive predictions for the empirical analysis. In Section 5 we give an overview of our data and offer some descriptive statistics of our main variables. In Section 6 the empirical analysis is presented and we report our main results. Finally, Section 7 concludes the paper. 


\section{Related literature}

Our paper contributes to, and bridges, two closely related strands of the literature on pharmaceutical markets: the literature on the effects of (i) parallel trade and (ii) price regulation of pharmaceuticals. Our paper is, to the best of our knowledge, the first one to study the effects of price regulation and parallel imports in conjunction, taking explicitly into account the vertical structure of the pharmaceutical industry.

The existing literature on parallel trade of pharmaceuticals consists of papers that are mainly concerned with the effects of parallel trade on prices, innovation and welfare. Ganslandt and Maskus (2004) study - theoretically and empirically - the effect of parallel trade on the pricing of pharmaceuticals. In their theory section they set up a simple model where a monopoly producer sells its product in a home and a foreign market. In the foreign country there is price regulation, which makes parallel import to the home country profitable. The authors find that for small trade costs the original producer will accommodate the import decisions of parallel traders and that the price in the home market falls as the volume of parallel imports rises. This theoretical prediction is confirmed by an empirical analysis using data from Sweden before and after they joined the EU in 1995 and had to allow for parallel imports. Having price data for the 50 largest substances for 1994-1999, and using instrumental variable methods to account for potential endogeneity in the entry decisions of parallel traders, they find that competition from parallel imports reduced prices by 12-19 percent.

Even if parallel trade leads to lower prices, the welfare implications are far from clearcut. Jelovac and Borday (2005) analyse theoretically the price and (static) welfare implications of permitting parallel imports of pharmaceuticals using a theory model where a monopoly producer sells a drug in two countries. The countries differ in health insurance coverage and the patients' utility of medical treatment. In their model parallel trade makes the prices converge between countries, it makes the patients in the importing (exporting) country better (worse) off, and it decreases the profit of the monopoly producer. However, the effect on total welfare is ambiguous. They find that permitting parallel imports improves welfare if countries only differ in patients' utility of drug treatment, while it reduces 
welfare if countries only differ in insurance coverage.

While the static welfare effects of parallel trade may be positive, a main concern is that it reduces the monopoly rent of the patent holder and may therefore have adverse effects on innovation incentives. However, Grossman and Lai (2008) offers a theoretical argument to the contrary. In a North-South model with innovation in the North and price regulation in the South, they show that allowing for parallel trade may in fact increase innovation incentives under optimal price regulation. The key to this insight is that regulators will optimally set different prices depending on whether or not parallel trade is allowed. This mechanism is absent in the two previously mentioned papers, where price regulation is either exogenous (Ganslandt and Maskus, 2004) or absent (Jelovac and Borday, 2005). ${ }^{5}$

The empirical studies on parallel trade of pharmaceuticals are mainly concerned with price and competition effects of such trade. In addition to the aforementioned study by Ganslandt and Maskus (2004), we would like to highlight the contributions by Kanavos and Costa-Font (2005), Kyle (2010) and Granlund and Köksal (2011). Using data from 30 countries, Kyle (2010) examines the effect of both potential and actual entry of parallel imports on prices of original drugs. She also finds that parallel import reduces prices, but the effects are weaker than those reported by Ganslandt and Maskus (2004). On the contrary, Kanavos and Costa-Font (2005) estimate the effect of the market share of parallel imports on price competition, but do not find statistically significant effects. Finally, Granlund and Köksal (2011) study whether the Swedish mandatory substitution reform in 2002 increased competition from parallel imports. The reform imposed reference pricing also on the on-patent drugs on the Swedish market. They use a difference-indifferences estimation on monthly data for a panel of all on-patent prescription drugs sold in Sweden during the 40 months from January 2001 through April 2004. On average, facing competition from parallel imports caused a 15-17 percent fall in prices. While the reform increased the effect of competition from parallel imports, it was only by 0.9 percent.

\footnotetext{
${ }^{5} \mathrm{~A}$ related mechanism is present in the analysis by Pecorino (2002), who discusses whether the US should allow for parallel imports of prescription drugs from Canada. He develops a theory model in which the price of the drug in the foreign country (Canada) is determined by Nash bargaining between the monopoly producer and the foreign government. Thus, international price discrimination occurs because of monopsony power by payers. In this setting, parallel trade (back into the home country) will affect the negotated price in the foreign country in a way that can make the producer better off.
} 
The present paper differs from all the above-mentioned papers in two important aspects. First, neither of these studies take explicitly into account the vertical structure of the pharmaceutical industry when assessing the effects of parallel trade; more specifically, how parallel trade affects pharmacies' pricing incentives, which in turn affect the relative bargaining position of pharmacies (or wholesalers) vis-á-vis the patent-holding producer. ${ }^{6}$ Second, while the above-mentioned studies are concerned about the effects of parallel trade per se, we focus instead on how the presence of parallel trade affect the impact of price regulation.

There are several papers that study the impact of price regulation of pharmaceuticals. One strand focuses on the impact on innovation incentives. Giaccotto, Santerre and Vernon (2005), Vernon (2005) and Golec and Vernon (2006) report results suggesting that strict price control is harmful for pharmaceutical firms' profits and R\&D spending. Moreover, Kyle (2007) uses cross-country data and finds that the use of price controls has a negative impact on both the extent and timing of the launch of new drugs in national markets.

Another strand focuses on the impact of price regulation on competition, pricing and expenditures in the off-patent market. Danzon and Chao (2000) argue that price regulation in pharmaceutical markets tends to drive out competition and may therefore be counterproductive. They use data from seven countries for 1992, and find evidence that support their claim for the off-patent market segment, where brand-name products face competition from generic versions. Recent papers by Brekke, Grasdal and Straume (2009) and Brekke, Holmås and Straume (2011a) show that the use of reference pricing may be more effective than price cap regulation in reducing pharmaceutical prices and expenditures. $^{7}$

We contribute to the literature on price regulation of pharmaceuticals by (in contrast to the above-mentioned papers) analysing how the presence of parallel trade affects the

\footnotetext{
${ }^{6}$ Maskus and Chen (2004) and Chen and Maskus (2005) study parallel trade and vertical price formation. Their starting point, which is usually ignored in the literature, is that the profitability of parallel trade is determined by cross-country differences in producer prices and not retail prices. In a model where a monopoly producer sells its product directly to consumers in one country and through an independent retailer in the other country, the producer has an incentive to offer a lower price to the independent retailer, but this makes parallel trade profitable. There is no price regulation in this model though, and the set-up does not particularly fit the characteristics of pharmaceutical markets.

${ }^{7}$ See also Brekke, Holmås and Straume (2013) for the effect of pharmacy margins on sales of brandnames and generics, and prices and expenditures.
} 
impact of price cap regulation on profits, prices and pharmaceutical expenditures.

\section{The Norwegian pharmaceutical market}

The total sales of pharmaceuticals in Norway amount to almost 20 billion Norwegian crowns (NOK) in 2012. ${ }^{8}$ In this paper we focus on sales of prescription drugs that are under patent protection. According to LMI (2013), the sales of prescription drugs cover 90 percent of the total sales, whereas the sales of patent-protected products amount to almost 70 percent of the total market.

In the patent-protected market segment, the original brand-name producers potentially face competition from parallel importers. Norway has adopted the EU legislation, which means that parallel traders are free to import (export) pharmaceuticals from EU member countries (Norway) to Norway (EU member countries). National regulations or firm behaviour that obstruct parallel trade are not allowed. However, parallel traders have to repack the original drug, and usually relable the products by replacing the company name of the original brand-name producer with their own. The sales of parallel-imported drugs in Norway are fairly low, probably because of a fairly low price level of pharmaceuticals in Norway relative to other European countries, especially on patent-protected substances. $^{9}$. In 2012 sales of parallel-imported drugs amounted to 3.6 percent of the total pharmaceutical sales.

All prescription drugs on the Norwegian market are subject to price cap regulation. The price cap is based on prices of the same product in a set of foreign countries; a scheme often called international reference pricing (IRP) or external referencing. While many countries use IRP, the set of reference countries and the price fixing rules vary. Norway uses a fairly small sample of nine European countries (Austria, Belgium, Denmark, Finland, Germany, Ireland, the Netherlands, Sweden, and UK) as reference. The pharmaceutical companies report wholesale prices of their drugs in the reference countries, and then the Norwegian Medicines Agency (NOMA) sets the price cap equal to the average of the three lowest prices. The price caps are usually revised annually, but at different dates for different

\footnotetext{
${ }^{8} 1$ Euro is about 8 NOK, 1 US dollar is about 6 NOK, and 1 British pound is about 10 NOK.

${ }^{9}$ See Brekke, Holmås and Straume (2011b).
} 
drugs. To obtain the maximum price at retail level, the NOMA sets a maximum mark-up the pharmacies can add to each product. The regulated mark-up is partly a fixed fee (22 NOK) and partly a percentage add-on (7 percent up to 200 NOK and 4 percent above 200 NOK). ${ }^{10}$ The price cap is common to all products with the same substance irrespective of whether the drug is an original brand-name, a parallel-imported or a generic version.

While wholesale and retail prices are subject to price cap regulation, producer prices are determined in negotiations between producers and wholesalers. The Norwegian market is concentrated at both upstream and downstream level. Thus, both producers and wholesalers are likely to have bargaining power. The original brand-name producers have a fairly strong bargaining position for products that are under patent protection. For these drugs the wholesalers cannot threaten with promoting generic sales. ${ }^{11}$ For patent-protected substances, the main competitive threat is from parallel-imported products, which is exactly what we will analyse in the next section.

At downstream level the Norwegian market is dominated by three wholesalers (Alliance Healthcare, NMD Grossisthandel, and Apokjeden Distribusjon) who purchase and distribute all pharmaceuticals that are sold on the market. The three wholesalers also own most (85 percent) of the pharmacies. The table below describes the pharmacy market.

\section{[ Table 1 about here ]}

The largest wholesaler is Apokjeden Distribusjon who owns pharmacies belonging to the chain called Apotek 1. The second largest wholesaler is NMD Distribusjon who owns Vitusapotek pharmacies and controls the franchise chain called Ditt Apotek. NMD Distribusjon also serves Sykehusapotek who are pharmacies owned by (and located at) public hospitals. Finally, Alliance Healthcare owns the Boots/Alliance pharmacies and also distributes pharmaceuticals to the independent pharmacies.

There are a couple of regulations on wholesalers that should be mentioned. ${ }^{12}$ First,

\footnotetext{
${ }^{10}$ For example, for a drug with a maximum wholesale price of 300, the maximum mark-up the pharmacy can charge is $22+200 * 0.07+100 * 0.04=40$. Thus, the maximum retail price of the product is then 340 NOK.

${ }^{11}$ See the paper by Brekke, Holmås and Straume (2013) for a study on the incentives of pharmacies to promote generic drugs instead of brand-names.

${ }^{12}$ More information about the regulations can be found on the webpage of NOMA;
} 
the wholesalers are required to store and deliver all pharmaceuticals that are demanded by patients or prescribed by their doctors. Thus, exclusive dealing or exclusive sales contracts between producers and wholesalers are not feasible. Second, producers are not allowed to sell products directly to pharmacies, but need to reach an agreement with the wholesalers in order to obtain sales. Third, wholesalers are required to report the gross and net transacted producer prices to the government, and are not allowed to include side-payments in their contracts with the producers. ${ }^{13}$

Finally, individuals in Norway are insured against medical expenditures by compulsory social insurance collected through general taxation. The insurance covers prescription drugs that are used to treat illnesses that last for some time (non-acute) and are sufficiently severe (non-trivial). For non-reimbursable prescription drugs, patients have to pay the full price charged by the pharmacy. For the reimbursable drugs, patients pay 38 percent of the price of the drug, but only up to certain expenditure caps per script and per year. If the pharmaceutical expenditures exceed these amounts, there is 100 percent insurance coverage. The price cap regulation applies to all prescription drugs irrespective of whether or not the drug is reimbursable.

\section{Theoretical model}

Consider a patent-protected brand-name drug that is sold in two countries, "domestic" and "foreign", by the original brand-name producer. The producer prices in the two countries are $w$ and $v$, respectively. In the domestic country the drug is distributed by a monopoly pharmacy and the producer price, $w$, is a result of bargaining between the producer and the pharmacy. ${ }^{14}$ We consider the case where $w>v$ in equilibrium, implying that there is scope for arbitrage which is assumed to be exploited by parallel-trading firms. For simplicity, we assume that the market for parallel-traded drugs is perfectly competitive. Abstracting from transportation costs, this implies that the domestic pharmacy can import parallel-

\footnotetext{
http://legemiddelverket.no/English/Import_wholesaling_retailing/Sider/default.aspx

${ }^{13}$ Initially, the reason for this regulation was that the government based the (internal) reference price for substances with generic competition on the producer prices. However, this reference pricing scheme is abolished, but the regulation is preserved for monitoring and planning purposes of the health authority.

${ }^{14}$ In the theoretical model we do not distinguish between wholesalers and pharmacies. This corresponds well with the Norwegian market where 85 percent of pharmacies are vertically integrated with wholesalers.
} 
traded drugs at a price $v$. Domestic retail prices for the original and the parallel-traded drugs are given by $p_{0}$ and $p_{1}$, respectively.

In the domestic market there is a continuum of consumers demanding the brand-name drug. The consumers differ in their willingness-to-pay $(\theta)$ for the drug treatment, where $\theta \sim U[0,1]$. The utility of a consumer with valuation $\theta$ is given by

$$
U=\left\{\begin{array}{cc}
\theta-\alpha p_{0} & \text { if buying the original drug } \\
\gamma \theta-\alpha p_{1} & \text { if buying a parallel-imported drug }
\end{array},\right.
$$

where $\alpha \in(0,1)$ is the coinsurance rate. The residual share $(1-\alpha)$ of the price is covered by medical insurance. The parameter $\gamma \in(0,1)$ reflects our assumption that consumers attach a higher value to the original brand-name product than the parallel-imported product. The difference in consumer valuation captures the reputation effect related to company name. The parallel importer cannot market the product using the brand-name producer's name, but is required to repack and relabel the product using its own company name.

In an equilibrium where both product types are sold, consumers with high (low) willingness-to-pay demand the original (parallel-imported) brand-name drug. The consumer who is indifferent between purchasing the original and the parallel-imported drug is characterised by

$$
\theta_{0}=\frac{\alpha\left(p_{0}-p_{1}\right)}{1-\gamma}
$$

while the consumer who is indifferent between buying the parallel-imported drug and refrain from drug consumption is characterised by

$$
\theta_{1}=\frac{\alpha p_{1}}{\gamma}
$$

Demand for, respectively, the original and parallel-imported drugs, are therefore given by

$$
\begin{gathered}
y_{0}=\int_{\theta_{0}}^{1} d s=1-\theta_{0}, \\
y_{1}=\int_{\theta_{1}}^{\theta_{0}} d s=\theta_{0}-\theta_{1} .
\end{gathered}
$$


The profit of the original brand-name producer is given by

$$
\pi_{0}=(w-c) y_{0}+(v-c) y_{1}
$$

where $c \in(0, v)$ is the marginal cost of producing the drug. The first term is the profit from direct sales in the domestic country, whereas the second term is the profit from sales to parallel traders. For simplicity, and without loss of generality, we ignore the residual profits from direct sales in the foreign country, which are independent of the parallel trade and the pricing decisions in the domestic market.

Finally, the profit of the domestic pharmacy is given by

$$
\pi_{D}=\left(p_{0}-w\right) y_{0}+\left(p_{1}-v\right) y_{1}
$$

We consider the following two-stage game:

Stage 1 The domestic pharmacy and the original producer bargain over the producer price $w$.

Stage 2 The domestic pharmacy chooses retail prices and drug consumption takes place.

We assume that domestic retail prices are subject to price cap regulation. We consider the case where, in equilibrium, the price cap binds for the original product. Given our demand assumptions, an equilibrium where both product types are sold must necessarily have a retail price for the parallel-imported drug below the price cap.

\subsection{Benchmark: No parallel trade}

As a benchmark for comparison, let us briefly consider the case where parallel imports of patented drugs are prohibited. In this case, domestic demand for the original drug is given by

$$
\widetilde{y}_{0}=1-\alpha p_{0}
$$


The profits of the brand-name producer and the pharmacy are then given by, respectively,

$$
\widetilde{\pi}_{0}=(\widetilde{w}-c) \widetilde{y}_{0}
$$

and

$$
\widetilde{\pi}_{D}=\left(p_{0}-\widetilde{w}\right) \widetilde{y}_{0}
$$

where $\widetilde{w}$ is the bargained producer price in the absence of parallel imports.

Assuming Nash bargaining between the producer and the pharmacy, the producer price is given by

$$
\widetilde{w}=\arg \max \widetilde{\Omega}:=\beta \ln \widetilde{\pi}_{D}+(1-\beta) \ln \widetilde{\pi}_{0},
$$

where $\beta \in(0,1)$ is the relative bargaining strength of the pharmacy. If the price cap $\left(p_{0}\right)$ binds, the equilibrium producer price is given by

$$
\widetilde{w}=(1-\beta) p_{0}+\beta c .
$$

A binding price cap then implies ${ }^{15}$

$$
p_{0}<\frac{1+\alpha c}{2 \alpha}
$$

Producer and pharmacy profits are, respectively, given by

$$
\begin{gathered}
\tilde{\pi}_{0}=(1-\beta)\left(p_{0}-c\right)\left(1-\alpha p_{0}\right), \\
\tilde{\pi}_{D}=\beta\left(p_{0}-c\right)\left(1-\alpha p_{0}\right)
\end{gathered}
$$

whereas total drug expenditures are exogenously determined by the price cap, and given by

$$
\widetilde{T}:=p_{0} \widetilde{y}_{0}=p_{0}\left(1-\alpha p_{0}\right)
$$

The effects of price cap regulation on producer profits and total expenditures are

\footnotetext{
${ }^{15}$ The right-hand side of the inequality is simply the monopoly price the pharmacy would charge in absence of price cap regulation.
} 
relatively straightforward:

$$
\begin{gathered}
\frac{\partial \widetilde{\pi}_{0}}{\partial p_{0}}=(1-\beta)\left(1-\alpha\left(2 p_{0}-c\right)\right)>0 \text { if } p_{0}<\frac{1+\alpha c}{2 \alpha}, \\
\frac{\partial \widetilde{T}}{\partial p_{0}}=1-2 \alpha p_{0} \gtrless 0 .
\end{gathered}
$$

Stricter price cap regulation unambiguously reduces both producer and pharmacy profits. ${ }^{16}$ Although a lower retail price leads to higher sales, the producer price is bargained downwards. As long as the price cap binds, the reduction in producer prices more than outweighs the increase in sales, leading to lower producer profits. The more bargaining power the pharmacy has, the larger is the negative effect of stricter price cap regulation on producer profits.

The effect of price cap regulation on total expenditures is a priori ambiguous, though, since a lower retail price leads to increased drug consumption. Therefore, the effect on expenditures depends on the price elasticity of drug demand. If the price cap is sufficiently low to begin with, stricter price cap regulation will always reduce total expenditures.

\subsection{Parallel imports}

Suppose now that the original brand-name producer faces competition from parallel importers. Since parallel-imported drugs are (by assumption) vertically differentiated from the original drug, it is profitable for the pharmacy to price these drugs below the regulated price cap. ${ }^{17}$ Substituting from (2)-(5) into (7) and maximising $\pi_{D}$ with respect to $p_{1}$, the profit-maximising retail price of parallel-imported drugs is given by

$$
p_{1}\left(p_{0}, w\right)=\gamma p_{0}-\frac{1}{2}(\gamma w-v)
$$

\footnotetext{
${ }^{16}$ Obviously, a lower price cap reduces also pharmacy profits given that the price cap is binding:

$$
\frac{\partial \widetilde{\pi}_{D}}{\partial p_{0}}=\beta\left(1-\alpha\left(2 p_{0}-c\right)\right)>0 \quad \text { if } \quad p_{0}<\frac{1+\alpha c}{2 \alpha} .
$$

${ }^{17}$ We consider the case where it is profitable for the pharmacy to sell both the original and parallelimported drugs. This requires that parallel-imported drugs are priced lower than the original drug.
} 
As expected, a lower price cap (which determines the price of the original drug) reduces the optimal retail price charged for parallel-imported drugs. Notice also that a higher producer price for the original drug will have the same effect. If the pharmacy obtains a lower profit margin on the original drug, the profit-maximising response is to steer demand towards parallel-imported drugs by lowering their price.

With a retail price given by (19), sales for the two drug versions are given by

$$
y_{0}\left(p_{0}, w\right)=1-\alpha p_{0}-\frac{\alpha(\gamma w-v)}{2(1-\gamma)}
$$

and

$$
y_{1}(w)=\frac{\alpha(\gamma w-v)}{2 \gamma(1-\gamma)}
$$

Notice that, with a binding price cap for the original drug, the original producer price affects sales of the two drug versions through the pharmacy's pricing of the parallelimported drugs. A higher original producer price reduces the pharmacy's profit margin on original drug sales. The pharmacy will optimally respond by lowering the retail price of the parallel-imported drugs, which reduces (increases) the sales of the original (parallelimported) drugs. We also see from (21) that the difference in producer prices must be sufficiently large, $w>v / \gamma$, for the pharmacy to find it profitable to sell both product types.

At the first stage of the game, when the players anticipate that the retail prices will be given by $p_{0}$ and $p_{1}\left(p_{0}, w\right)$, the bargained producer price for the original drug is given by

$$
w^{*}=\arg \max \Omega:=\beta \ln \pi_{D}+(1-\beta) \ln \pi_{0} .
$$

On general form, the first-order condition for an interior solution to this bargaining problem, i.e., $w^{*} \in\left(\frac{v}{\gamma}, p_{0}\right)$, is given by

$$
\frac{\partial \Omega}{\partial w}=\frac{\beta}{\pi_{D}} \frac{\partial \pi_{D}}{\partial w}+\frac{(1-\beta)}{\pi_{0}} \frac{\partial \pi_{0}}{\partial w}=0
$$


where

$$
\begin{gathered}
\frac{\partial \pi_{D}}{\partial w}=-y_{0}\left(p_{0}, w\right)<0 \\
\frac{\partial \pi_{0}}{\partial w}=y_{0}\left(p_{0}, w\right)-\alpha\left(\frac{(\gamma w-v)+(1-\gamma) c}{2(1-\gamma)}\right)>0 .
\end{gathered}
$$

If the pharmacy has all the bargaining power, $\beta \rightarrow 1$, the outcome is a corner solution where $w \rightarrow c$ and there is no scope for profitable parallel imports. In the other extreme case, if the original producer has all the bargaining power, $\beta \rightarrow 0$, the outcome is, depending on the level of $p_{0}$, either a corner solution with $w \rightarrow p_{0}$ or an interior solution with $w<p_{0} \cdot{ }^{18}$

It is not feasible to obtain an explicit interior solution for $w^{*}$. However, we can use (23) to examine the comparative statics properties of the interior solution. We are foremostly interested in how the bargained producer price is affected by price cap regulation:

Proposition 1 Let the equilibrium producer price, $w^{*}$, be an interior solution to the Nash bargaining game between the original producer and the pharmacy. Stricter price cap regulation will then reduce (increase) the equilibrium producer price if the relative bargaining power of the pharmacy is sufficiently high (low).

\section{Proof. In Appendix.}

A reduction in the price cap leads, all else equal, to higher sales of the original drug. Contrary to the case of no parallel imports, this has two counteracting effects on the interior solution to the bargaining problem between the pharmacy and the brand-name producer. For the pharmacy, an increase in sales of the original drug means that the profit loss of a higher producer price becomes larger, which strengthens the pharmacy's incentive to obtain a lower price in bargaining. For the original producer, on the other hand, higher sales increases the profit gain of a higher producer price, strengthening the firm's incentive to obtain a higher price in bargaining. Thus, the overall effect of a lower price cap on the bargained producer price depends on the relative bargaining power of the pharmacy and

\footnotetext{
${ }^{18}$ If $\beta=0$, the equilibrium producer price is given by

$$
w=\min \left\{p_{0}, \frac{v}{\gamma}+\frac{2(1-\gamma)\left(1-\alpha p_{0}\right)-\alpha c(1-\gamma)}{2 \alpha \gamma}\right\} .
$$
}


the original producer. If the bargaining power of the pharmacy (producer) is sufficiently strong, the former (latter) effect dominates and a price cap reduction will be followed by a reduction (increase) in the producer price.

It is worth emphasising how the original producer's incentives in the bargaining game change when the producer faces competition from parallel importers. Without parallel imports, the brand-name producer would like to obtain a price as close to the price cap as possible, and the bargained price is only constrained by the relative bargaining power of the two parties. Thus, a lower price cap would always lead to a lower bargained producer price (see Eq. (12)). However, with competition from parallel importers, the pharmacy would respond to a higher original producer price by reducing the retail price of parallel-imported drugs in order to steer demand away from the original drug version. This weakens the original producer's incentives to demand a higher producer price in bargaining. In fact, unless the price cap is very low, the brand-name producer would prefer to charge a producer price at a level below the price cap in order to stifle the pharmacy's incentives to steer demand towards parallel-imported drugs. Consequently, in an interior solution, the bargained producer price is constrained not only by the players' relative bargaining power but also by the producer's incentives to restrain competition from parallel importers. This affects qualitatively the relationship between the price cap and the producer's incentives in the bargaining game. All else equal, a lower price cap boosts the sales of the original drug at the expense of parallel-imported drugs. This makes it less urgent for the original producer to keep the producer price low in order to meet competition from parallel-importers. Consequently, the producer, if he has sufficient bargaining power, will obtain a higher producer price.

Put differently, competition from parallel importers shifts market power from the upstream to the downstream part of the industry, improving the relative bargaining position of the pharmacy vis-à-vis the producer of the original brand-name drug. However, stricter price cap regulation tends to weaken competition from parallel importers, shifting market power back towards the upstream part of the industry. The original producer can take advantage of this and obtain a higher producer price, if his relative bargaining power is sufficiently strong. 
Having established the relationship between the price cap and the bargained producer price of the original drug, we can proceed to assess the equilibrium effects of price cap regulation on the sales of the two product types and on the profits of the original brandname producer:

Proposition 2 (i) If $\partial w^{*} / \partial p_{0}>0$, stricter price cap regulation leads to higher sales of the original drug, lower sales of the parallel-imported drugs, whereas the effect on the profits of the original producer is ambiguous.

(ii) If $\partial w^{*} / \partial p_{0}<0$, stricter price cap regulation leads to higher sales of both drug versions and higher profits for the original producer.

Proof. In Appendix.

Regardless of how the bargained producer price responds to a change in the binding price cap, stricter price cap regulation leads to higher sales of the original drug, which is quite intuitive. If there is a positive relationship between the price cap and the producer price, the increased sale of the original drug due to stricter price cap regulation comes at the expense of parallel-imported drug sales. Again, this is quite intuitive. In this case, stricter price cap regulation has an ambiguous effect on the profits of the original producer. Sales in the domestic market increases (although part of this sales increase replaces foreign sales to parallel importers), but this is counteracted by a lower producer price in the domestic market.

However, if a lower price cap leads to a higher original producer price, stricter price regulation will, perhaps counterintuitively, increase the sales of both product types. From (21) we see that, for a given original producer price $w$, and when the pharmacy sets $p_{1}$ optimally, the demand for parallel-imported drugs does not depend directly on the price cap. The pharmacy will optimally adjust the price of parallel-imported drugs to any changes in the binding price cap, in a way that makes the demand for parallelimported drugs insensitive to the level of the price cap. ${ }^{19}$ Stricter price cap regulation then only affects parallel-imported drug sales through changes in the original producer price. More specifically, if a lower price cap leads to a higher producer price, the corresponding

\footnotetext{
${ }^{19}$ This particular feature results from the linearity assumpntions of the model.
} 
reduction in pharmacy profit margins on sales of the original drug gives the pharmacy a strong incentive to steer demand towards parallel-imported drugs. The pharmacy will therefore reduce $p_{1}$ to an extent where demand for parallel-imported drugs increases.

In the latter case, where $\partial w^{*} / \partial p_{0}<0$, the original producer unambiguously benefits from stricter price cap regulation. A lower price cap leads to a sales increase to the domestic market, both directly to the domestic pharmacy and indirectly via higher demand from parallel importers. On top of that, the profit margin on direct sales to the domestic market increases.

In the presence of competition from parallel importers, total drug expenditures in the domestic market is given by

$$
T:=p_{0} y_{0}+p_{1} y_{1}
$$

The effect of price cap regulation on total expenditures is then given by

$$
\frac{\partial T}{\partial p_{0}}=y_{0}+p_{0} \frac{\partial y_{0}}{\partial p_{0}}+\frac{\partial p_{1}}{\partial p_{0}} y_{1}+p_{1} \frac{\partial y_{1}}{\partial p_{0}} \lessgtr 0
$$

As in the benchmark case of no parallel imports, the effect of stricter price cap regulation on total drug expenditures is a priori ambiguous. However, there are now more sub-effects to consider, and the strength of the previous sub-effects are likely to be different.

The sum of the first and second terms in (27) is the effect on original drug expenditures. As in the benchmark case, a lower price cap leads to increased sales of the original drug, making the effect on expenditures ambiguous. The sum of the third and fourth terms is the effect on expenditures of parallel-imported drugs. Since the pharmacy will respond to a price cap reduction by reducing the retail price of parallel-imported drugs, the third term is positive. The sign of the fourth term depends on the sign of $\partial w^{*} / \partial p_{0}$. If $\partial w^{*} / \partial p_{0}>0$, stricter price cap regulation leads to a reduction in the sales of parallel-imported drugs. On the other hand, if $\partial w^{*} / \partial p_{0}<0$, stricter price cap regulation leads to an increase in the demand for both product types, which reduces the scope for an overall reduction in drug expenditures.

However, even if the demand for parallel-imported drugs falls as a result of a lower price cap, it is by no means certain that the presence of parallel imports makes price 
regulation a more effective instrument for curtailing drug expenditures. The reason is that the net demand loss for parallel-imported drugs is caused by consumers who switch to the original drug, which has become relatively cheaper as a result of a lower price cap. Thus, even if stricter price cap regulation leads to lower prices for both product types, total drug demand increases and a larger share of demand is directed towards the most expensive drug.

\subsection{Discussion and empirical predictions}

Although we cannot say anything conclusive about whether and how the effectiveness of price regulation as an instrument to control drug expenditures is determined by the presence of parallel imports, the results reported in Proposition 2 clearly suggest that stricter price cap regulation is less harmful for the original producer in markets with parallel imports. Obviously, allowing for parallel imports will reduce the profits of the original producer. However, given that parallel imports are allowed, the original producer is less harmed by price cap regulation and might even benefit from it.

This has some potentially interesting implications for the optimal use of price cap regulation as a policy instrument. A standard concern about price regulation in on-patent drug markets is that, although it might improve static efficiency by reducing total drug expenditures, it will also reduce the patent-holder's return on its investment in drug innovation and therefore reduce dynamic efficiency. Our analysis suggests that the dynamic efficiency concern of using (relatively strict) price cap regulation should be less of a worry in markets where parallel imports are allowed. In such markets, it might actually be the case that stricter price cap regulation leads to both lower expenditures and higher profits for the brand-name producer; in other words, that stricter price cap regulation improves both static and dynamic efficiency.

If stricter price regulation improves both static and dynamic efficiency in markets with parallel imports, the policy implication that follows is that a policy of allowing parallel imports of on-patent drugs should optimally be complemented by relatively strict price regulation. The negative effects of the former policy (in terms of dynamic efficiency) may be counteracted by stricter price cap regulation, shifting rents from the downstream to the 
upstream part of the industry - from pharmacies to producers. From a dynamic efficiency perspective, the optimal policy package should allocate as much of the total industry rents as possible to the upstream part of the industry. Under certain conditions, as we have seen, price cap regulation has precisely this effect in markets where the original producer faces competition from parallel importers. Thus, our analysis suggests that both policies - allowing parallel imports and enforcing a relatively strict price regulation - might be part of the optimal policy package, making these instruments policy complements rather than policy substitutes.

Based on our theoretical analysis, we make the following empirical predictions that will be tested econometrically:

(i) In markets with parallel imports, a reduction in the price cap leads to an increase in both sales and market share of the original drug.

(ii) In markets without parallel imports, a lower price cap reduces both the producer price and the profits of the brand-name producer, whereas in markets with parallel imports both these effects are smaller and might even be positive.

We will also test the effect of stricter price cap regulation on total drug expenditures, although our theoretical analysis does not allow us to make any clear-cut predictions besides the effect being theoretically ambiguous.

\section{$5 \quad$ Data and descriptive statistics}

For the empirical analysis we have obtained public register data from the Norwegian Institute of Public Health. Our data are extracted from two different databases; the Prescription database and the Wholesale database. The Prescription database contains information about all prescription bound sales at pharmacy level in Norway from 2004 and onwards. From this database we have obtained monthly data on the price caps (set by the regulator), the retail prices (charged by the pharmacy), and sales volumes both for parallel-imported and original drugs over a four-year period (2004-2007). Prices and volumes are in defined daily doses (DDD) per pack sold by the pharmacies. The data also 
include detailed information about product name, manufacturer, marketing firm, launch date, pack size, strength, presentation form (e.g., tablet, capsule, injection), etc. From the Wholesale database we have got monthly information about prices (per DDD) at producer (ex-manufacturer) level for each pack purchased by the wholesalers. We merge the data from these two databases using the pack identity, which gives us prices at both retail and producer level for original and parallel-imported drugs.

We define our sample by excluding substances where the brand-name product has competition from generic versions. This leaves 165 substances with sales of brand-name products that could be original or parallel-imported. ${ }^{20}$ Table 2 below provides descriptive statistics of our sample.

\section{[ Table 2 about here ]}

In the table the sample is divided according to whether or not we observe parallelimported drugs within a substance. We see that for 110 (of the 165) substances there is no parallel import in our sample period. For the residual 55 substances with parallel import, we report prices and sales separately for original and parallel-imported drugs. A first observation is that the price cap tends to be binding for the original drugs, whereas parallel-imported drugs tend to be priced slightly lower than the price cap and thus the original brand-name product. In Table A in the Appendix we report prices for each of the 55 substances with parallel import. These figures show the same pattern for almost every substance. Thus, these descriptive statistics fit the assumptions of our theoretical model.

A second observation is that the average price caps are lower for parallel-imported drugs than for locally-sourced drugs. This is likely to be due to parallel traders importing typically larger packs, which tend to have lower price cap per DDD than smaller packs. In our sample the average pack size of parallel-imported drugs is 52 DDDs, whereas the same figure for the original drugs is 40.8 . We also see from the table that the brand-name producers offer a wider range of products (258) than the parallel traders (186). Finally, we observe that the producer prices are substantially lower than the retail prices, providing the pharmacy chains with a large margin for both parallel-imported and original drugs.

\footnotetext{
${ }^{20} \mathrm{~A}$ complete list of the substances in our sample can be provided upon request.
} 
In the empirical analysis we exploit variation within substances or products (packs) to investigate the effect of the price cap on our dependent variables. Thus, an important factor is the extent to which there is sufficient within variation in the price cap variable. One way to display the within variation is simply to graph the price cap over time for each substance. As our sample consist of 165 substances, we only show this variation for the six largest (in sales value) substances with and without parallel import; see Figures 1 and 2 below.

[ Figure 1 and 2 about here ]

As we see from the figures, there is substantial variation in the price caps over time. These changes are due to revisions by the regulator, as explained in Section 3. An alternative way to investigate the within variation is to decompose the standard deviation into between and within components, which is reported in Table 3 below.

[ Table 3 about here ]

The table shows substantial within variation in the price cap variable.

\section{Empirical method and results}

When testing the main predictions from our theoretical analysis, we estimate the following fixed effect model:

$$
y_{i t}=\alpha+\beta P_{i t}+\gamma_{i}+\delta_{t}+\varepsilon_{i t}
$$

where $i$ denotes product (substance or pack) and $t$ denotes time period. The dependent variable $y_{i t}$ is either market shares, sales (DDD), producer prices, profits or total expenditures; $P_{i t}$ is the price cap; $\gamma_{i}$ is a product fixed effect; $\delta_{t}$ is a period fixed effect; and $\varepsilon_{i t}$ is a mean-zero error term. Since our variables are typically not normally distributed, we use the natural logarithm of all variables (except for market shares), which implies that we estimate elasticities.

The product fixed effect $\left(\gamma_{i}\right)$ captures time-invariant, unobserved (and observed) fac- 
tors that affect our dependent variables. This could be product characteristics such as the share of brand-loyal consumers and physicians, type of patients (age, gender), type of disease (chronic or acute), type of product (tablet, capsule, injection), etc. The period fixed effect $\left(\delta_{t}\right)$ captures time trends in our dependent variables that are common across products.

Our empirical strategy is to exploit that the variation in the price cap $\left(P_{i t}\right)$ is exogenous. However, since the profitability of parallel trade is related to cross-country price differences and we only observe domestic prices in Norway, we could in principle have an omitted variable problem. This would generate biased estimates if the foreign producer prices are correlated both with the price cap level in Norway and our dependent variables. If this is the case, then a price reduction in foreign countries would result in a lower price cap in Norway, while the profit margin of parallel trade could potentially be constant (and in any case lower). Thus, we would underestimate the effect of variation in the price cap on our dependent variables.

However, this is unlikely to be a problem in our analysis. As explained in Section 3, the price cap for each product is revised annually (at different dates), and will be adjusted if the exchange rate and/or the prices (of the same product) in reference countries have changed. The variation in exchange rates is obviously exogenous. Moreover, since the price cap is set as the average of the three lowest prices in the reference countries, the scope for parallel export from these countries to Norway is therefore very limited. In addition, these countries are not typical low-price countries. Thus, the variation in the price cap in Norway is unlikely be correlated with the purchasing prices of the parallel importers abroad.

We estimate the effects of price cap regulation on different samples. First, we run the regression on the full sample of 165 substances. This means that we include the substances that potentially could have parallel import, but de facto do not have parallel import. Second, we run the regressions separately for the 110 substances with no parallel imports and the 55 substances where we observe parallel imports. This enables us to measure the different effects that variation in price cap levels have on the original brandnames depending on whether or not there is competition from parallel imports. 


\subsection{Market shares and sales}

We first estimate the effects of price regulation on market shares and sales of original and parallel-imported products. In this regression we use information at substance level, since parallel-imported drugs in many cases differ from original drugs in pack size, presentation form, etc.

\section{[ Table 4 about here ]}

As can be seen from Table 4, we find significant effects of price cap regulation on markets shares, but the effect is as expected much stronger for substances that have de facto competition from parallel import. For the 55 substances with parallel imports, a 10 percent reduction in the price cap results in almost five percent increase (reduction) in the market share of the locally-sourced (parallel-imported) drug. ${ }^{21}$ Thus, stricter price cap regulation tends to drive out competition from parallel-imported drugs.

Since price changes may affect not just the relative sales of original and parallelimported drugs, but also their sales in absolute terms, we estimate the effect of price regulation on the sales (in DDD). In this regression we use information at the pack (not substance) level to exploit the variation in our data.

\section{[ Table 5 about here ]}

Table 5 shows that the effect of price regulation on the sales of original drugs varies substantially according to whether or not they have competition from parallel imports. For all 165 substances, our results show an elasticity of -0.48 . When splitting the sample into substances with and without parallel imports, we see that the effect of price cap regulation on the sales of original drugs is much stronger in the presence of parallel imports $(-0.86$ vs. -0.35$)$. This confirms our first prediction. As explained in the theory section, a lower price cap (in markets with parallel import) not only expand the market, but also shifts sales from parallel-imported drugs to original drugs. The price elasticity for parallelimported drugs is even higher than for the original drugs. This asymmetry in elasticities

\footnotetext{
${ }^{21}$ In a linear-log model, the expected change in $Y$ of a 1 percent increase in $X$ is approximately $\widehat{\beta} / 100$.
} 
is likely to due to the fact that parallel-imported drugs have a lower market share (sales).

\subsection{Producer prices and profits}

We expect the effects of price cap regulation on producer prices and profits to depend crucially on whether or not there is parallel import, as stated in our second prediction. We first test the effect of price cap regulation on producer prices of both original and parallel-imported drugs.

\section{[ Table 6 about here ]}

Table 6 shows that for all 165 substance a 10 percent reduction in the price cap leads to on average 12.7 percent reduction in the producer price. ${ }^{22}$ As shown in the theory section, the effect of a lower price cap results in lower producer prices in absence of parallel import, while the effect in the presence of parallel import depends on the bargaining power of the producer relative to the pharmacy. Consistent with our second prediction, we find that the effect of price cap regulation is weaker for substances with parallel import. However, the effect is positive, with an elasticity of 1.08, suggesting a relatively high bargaining power of pharmacy chains in the presence of parallel imports. As expected, the effect of price cap regulation on the price of the parallel importer is negative, but weaker than for the original drug.

We then test the effect of price regulation on the profits to the brand-name producer and the parallel trader. We use sales revenues per product as a proxy for firms' profits. For locally-sourced drugs, this should be a good proxy since the cost of producing the drugs is likely to be constant over time. The correlation between sales revenues and profits is probably weaker for parallel importers since their profits depend on foreign prices.

\section{[ Table 7 about here ]}

Table 7 shows, as expected, that a stricter price cap is harmful for the brand-name producer in markets without parallel imports. However, for markets with parallel imports, we find

\footnotetext{
${ }^{22}$ The reason that the elasicity can exceed one is that the producer price is much lower than the price cap enforced at retail (pharmacy) level. Table 1 shows that the average price cap is 71.78 NOK, while the average producer price of locally sourced drug is 49.8 NOK.
} 
a non-significant effect of price regulation on the profits to brand-name producer. This is consistent with our second prediction. In markets with parallel imports, price regulation has a strong, positive effect on the brand-name producers' sales, but a weaker, negative effect on prices. Our result shows that the these opposing effects offset each other. The effect of price regulation on the profits (sales revenues) of the parallel importer is as expected positive. A 10 percent reduction in the price cap results in a 28 percent reduction in profits due to reduction in sales and prices.

\subsection{Total expenditures}

In the final regression we estimate the effect of price regulation on total expenditures. We measure total expenditures at pharmacy (retail) level per substance. Total expenditures are simply the price per DDD times the sales volumes in DDDs for all products with the same substance. In absence of parallel import, a lower price cap reduces directly the pharmacy price of the brand-name product, but sales volumes (DDDs) increase, as shown in Table 4. In presence of parallel import, a lower price cap also shifts market shares from lower priced parallel-imported drugs to higher priced original drugs. Thus, the net effect of lower price regulation on total expenditures is ambiguous and may depend on whether or not the substance has competition from parallel-imported drugs, as explained in the theory section.

\section{[ Table 8 about here ]}

We see from table 8 that a lower price cap reduces total expenditures. For all 165 substances a 10 percent cut in the price cap leads to almost 6 percent reduction in total expenditures. Thus, the price effect dominates the sales effect. This is as expected since demand for prescription drugs is fairly price inelastic. We also see that price regulation is more effective in reducing expenditures for substances with parallel imports.

\section{Concluding remarks}

In this paper we have shown that the effect of price regulation on market outcomes and efficiency crucially depends on the presence of parallel imports. Assuming Nash-bargaining 
between an original brand-name producer and a monopoly pharmacy, we derive the following empirical predictions: (i) in markets with parallel imports, a reduction in the price cap leads to an increase in both sales and market share of the original drug; (ii) in markets without parallel imports, a lower price cap reduces both the producer price and the profits of the brand-name producer, whereas in markets with parallel imports both these effects are smaller and might even be positive. We also show that the effect of stricter price cap regulation on total drug expenditures is theoretically ambiguous.

The predictions are tested econometrically using data from Norway on monthly sales and prices for 165 substances in the period 2004-7. Consistent with our first prediction, we find that stricter price cap regulation drives out parallel imports resulting in higher market shares and sales of the original brand-name product. Consistent with our second prediction, we find that stricter price cap regulation reduces producer prices and profits to the brand-name producer, but the effect is weaker for substances with parallel imports. In fact, a lower price cap has no significant effect on the original producers' profits for substances with parallel imports. Finally, we find that stricter price cap regulation reduces total expenditures, and that the effect is stronger for substances with parallel imports.

Price cap regulation is a policy instrument to promote static efficiency in pharmaceutical markets by forcing prices closer to marginal production costs and reducing pharmaceutical expenditures. Our study shows that the existence of parallel imports makes price cap regulation more effective in promoting static efficiency. Thus, parallel imports and price regulation are policy complements, though stricter price cap regulation reduces the scope for parallel imports. More surprisingly, our results show that price cap regulation is less harmful to (and might even promote) dynamic efficiency in markets with parallel imports, as the effect on the original producers' profits of a lower price cap is less negative and might even be positive when there is competition from parallel import. However, this result needs to be interpreted with caution, since we do not explicitly model the $\mathrm{R} \& \mathrm{D}$ process or empirically test the impact of price regulation on measures of innovation. Clearly, a full welfare analysis of price cap regulation and parallel import is beyond the scope of our study and therefore left to future research. 


\section{Appendix}

\section{Proof of Proposition 1}

Assuming an interior solution of (22), and applying the implicit function theorem, we have

$$
\operatorname{sign}\left(\frac{\partial w^{*}}{\partial p_{0}}\right)=\operatorname{sign}\left(\frac{\partial^{2} \Omega}{\partial p_{0} \partial w}\right)
$$

where

$$
\frac{\partial^{2} \Omega}{\partial p_{0} \partial w}=\beta\left(\frac{\frac{\partial^{2} \pi_{D}}{\partial w \partial p_{0}} \pi_{D}-\frac{\partial \pi_{D}}{\partial w} \frac{\partial \pi_{D}}{\partial p_{0}}}{\pi_{D}^{2}}\right)+(1-\beta)\left(\frac{\frac{\partial^{2} \pi_{0}}{\partial w \partial p_{0}} \pi_{0}-\frac{\partial \pi_{0}}{\partial w} \frac{\partial \pi_{0}}{\partial p_{0}}}{\pi_{0}^{2}}\right)
$$

Substituting the equilibrium value of $p_{1}$ from (19), and the demand functions, (20)-(21), into the profit functions of the pharmacy and the original producer, yields

$$
\pi_{D}\left(p_{0}, w\right)=\frac{4 \gamma(1-\gamma)\left(p_{0}-w\right)\left(1-\alpha p_{0}\right)+\alpha(\gamma w-v)^{2}}{4 \gamma(1-\gamma)}
$$

and

$$
\pi_{0}\left(p_{0}, w\right)=(w-c)\left(1-\alpha p_{0}\right)-\frac{\alpha(\gamma w-v)(\gamma w-v+(1-\gamma) c)}{2 \gamma(1-\gamma)}
$$

From (A3) we derive

$$
\begin{gathered}
\frac{\partial^{2} \pi_{D}}{\partial w \partial p_{0}}=\alpha>0, \\
\frac{\partial \pi_{D}}{\partial w}=-y_{0}<0
\end{gathered}
$$

and

$$
\frac{\partial \pi_{D}}{\partial p_{0}}=1-2 \alpha p_{0}+\alpha w>0
$$

where the positive sign of (A7) follows from the assumption that the price cap is binding. Thus, the first term in (A2) is unambiguously positive. Using (A4) we derive

$$
\frac{\partial^{2} \pi_{0}}{\partial w \partial p_{0}} \pi_{0}-\frac{\partial \pi_{0}}{\partial w} \frac{\partial \pi_{0}}{\partial p_{0}}=-\frac{\alpha^{2}\left(\gamma^{2}(w-c)^{2}-(v-c)(v-\gamma c)\right)}{2 \gamma(1-\gamma)}<0 .
$$


The negative sign of (A8) is established by noticing that the numerator is monotonically increasing in $w$. Inserting the lowest value of $w$ that is compatible with an equilibrium where both product types have positive sales, $w=v / \gamma$, the numerator reduces to $\alpha^{2} c(1-\gamma)(v-c \gamma)>0$. Thus, the expression in (A8), and therefore the second term in (A2), is unambiguously negative for any $w \in\left(\frac{v}{\gamma}, p_{0}\right)$. Since (A2) consists of the sum of a

positive and a negative term, it follows, by continuity, that $\frac{\partial^{2} \Omega}{\partial p_{0} \partial w}>(<) 0$ if $\beta$ is sufficiently small (large). Consequently, $\frac{\partial w^{*}}{\partial p_{0}}>(<) 0$ if $\beta$ is sufficiently small (large). Q.E.D.

\section{Proof of Proposition 2}

From (20)-(21), the effects of the price cap on sales are given by

$$
\frac{\partial y_{0}}{\partial p_{0}}=-\alpha\left(1+\frac{\gamma}{2(1-\gamma)} \frac{\partial w^{*}}{\partial p_{0}}\right)
$$

and

$$
\frac{\partial y_{1}}{\partial p_{0}}=\frac{\alpha}{2(1-\gamma)} \frac{\partial w^{*}}{\partial p_{0}}
$$

The sign of (A10) is unambiguously positive (negative) if $\partial w^{*} / \partial p_{0}>(<) 0$. The sign of (A9) is unambiguously negative if $\partial w^{*} / \partial p_{0}>0$, whereas it is a priori ambiguous if $\partial w^{*} / \partial p_{0}<0$. From the proof of Proposition 1 we know that $\partial w^{*} / \partial p_{0}$ is "more negative" the lower is $\beta$. For the limit case of $\beta \rightarrow 0$ we can solve explicitly for $w^{*}$ and find an explicit expression for $\partial y_{0} / \partial p_{0}$, given by

$$
\left.\frac{\partial y_{0}}{\partial p_{0}}\right|_{\beta=0}=-\frac{\alpha}{2}<0 .
$$

Thus, the direct effect of a price cap reduction on the sales of the original drug always dominates the indirect effect via the bargained producer price, establishing a negative relationship between $y_{0}$ and $p_{0}$ regardless of the sign of $\partial w^{*} / \partial p_{0}$.

The effect of the price cap on the profit of the original brand-name producer is

$$
\frac{\partial \pi_{0}}{\partial p_{0}}=\frac{\partial w^{*}}{\partial p_{0}} y_{0}+\left(w^{*}-c\right) \frac{\partial y_{0}}{\partial p_{0}}+(v-c) \frac{\partial y_{1}}{\partial p_{0}} .
$$


If $\partial w^{*} / \partial p_{0}>0$, the first and last terms in (A12) are both positive, whereas the second term is negative, implying that the sign of the total effect is ambiguous. However, if $\partial w^{*} / \partial p_{0}<0$, all three terms are negative, giving an unambiguously negative total effect. Q.E.D.

\title{
Descriptive statistics: Substances with parallel imports
}

\author{
[ Table A here ]
}

\section{References}

[1] Brekke, K.R., Grasdal, A.L., Holmås, T.H., 2009. Regulation and pricing of pharmaceuticals: reference pricing or price cap regulation? European Economic Review, 53, $170-185$.

[2] Brekke, K.R., Holmås, T.H., Straume, O.R., 2011a. Reference pricing, competition, and pharmaceutical expenditures: theory and evidence from a natural experiment. Journal of Public Economics, 95, 624-638.

[3] Brekke, K.R., Holmås, T.H., Straume, O.R., 2011b. Comparing pharmaceutical prices in Europe: a comparison of prescription drug prices in Norway with nine Western European countries. SNF Report No. 11/11.

[4] Brekke, K.R., Holmås, T.H., Straume, O.R., 2013. Margins and market shares: pharmacy incentives for generic substitution. European Economic Review, 61, 116-131.

[5] Chen, Y., Maskus, K.E., 2005. Vertical pricing and parallel imports. Journal of International Trade and Economic Development 14, 1-18.

[6] Danzon, P., 1997. Price discrimination for pharmaceuticals: welfare effects in the US and the EU. International Journal of the Economics of Business, 4, 301-322. 
[7] Danzon, P.M., Chao, L.-W., 2000. Does regulation drive out competition in pharmaceutical markets? Journal of Law and Economics, 43, 311-357.

[8] Ganslandt, M., Maskus, K.E., 2004. Parallel imports and the pricing of pharmaceutical products: evidence from the European Union. Journal of Health Economics, 23, $1035-1057$.

[9] Giaccotto, C., Santerre, R.E., Vernon, J.A., 2005. Drug prices and research and development investment behavior in the pharmaceutical industry. Journal of Law and Economics, 48, 195-214.

[10] Golec, J.H., Vernon, J.A., 2006. European pharmaceutical price regulation, firm profitability, and R\&D spending. NBER Working Papers, 12676, National Bureau of Economic Research.

[11] Granlund, D., Köksal, M.Y., 2011. Parallel imports and mandatory substitution reform: a kick or a muff for price competition in pharmaceuticals? Scandinavian Working Papers in Economics 824, Umeå University.

[12] Grossman, G.M., Lai, E.L.-C., 2008. Parallel imports and price controls. RAND Journal of Economics, 39, 378-402.

[13] Jelovac, I., Bordoy, C., 2005. Pricing and welfare implications of parallel imports in the pharmaceutical industry, International Journal of Health Care Finance and Economics 5, 5-21.

[14] Kanavos, P., Costa-Font, J., 2005. Pharmaceutical parallel trade in Europe: stakeholder and competition effects. Economic Policy, 20, 751-798.

[15] Kyle, M.K., 2007. Pharmaceutical price controls and entry strategies. Review of Economics and Statistics, 89, 88-99.

[16] Kyle, M.K., 2010. Strategic responses to parallel trade. B.E. Journal of Economic Analysis and Policy 11(2).

[17] LMI, 2013. Tall of fakta 2013: Legemidler og helsetjeneste. Legemiddelindustrien (LMI), Oslo. 
[18] Maskus, K.E., Chen, Y., 2004. Vertical price control and parallel imports: theory and evidence. Review of International Economics 12, 551-570.

[19] Pecorino, P., 2002. Should the US allow prescription drug reimports from Canada? Journal of Health Economics 21, 699-708.

[20] Vernon, J.A., 2005. Examining the link between price regulation and pharmaceutical R\&D investment. Health Economics, 14, 1-16. 


\section{Figures and tables}

Figure 1. Variation in the price caps for the six largest (in sales value) substances without parallel imports.
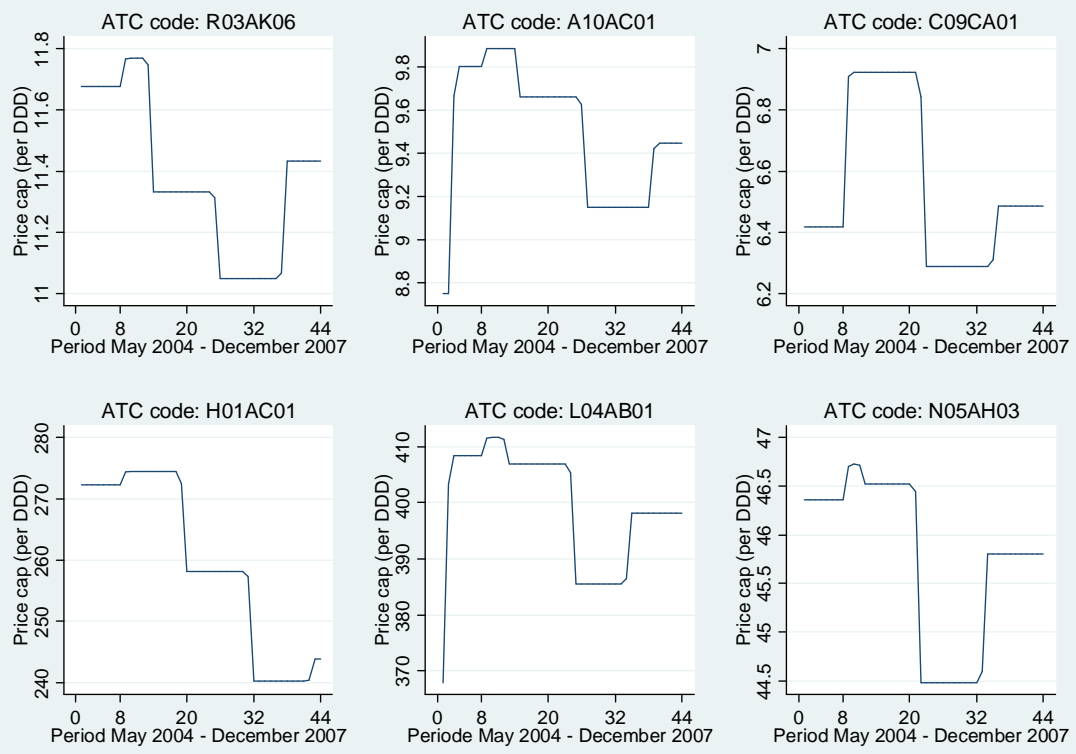

Figure 2. Variation in the price caps for the six largest (in sales value) substances with parallel imports.
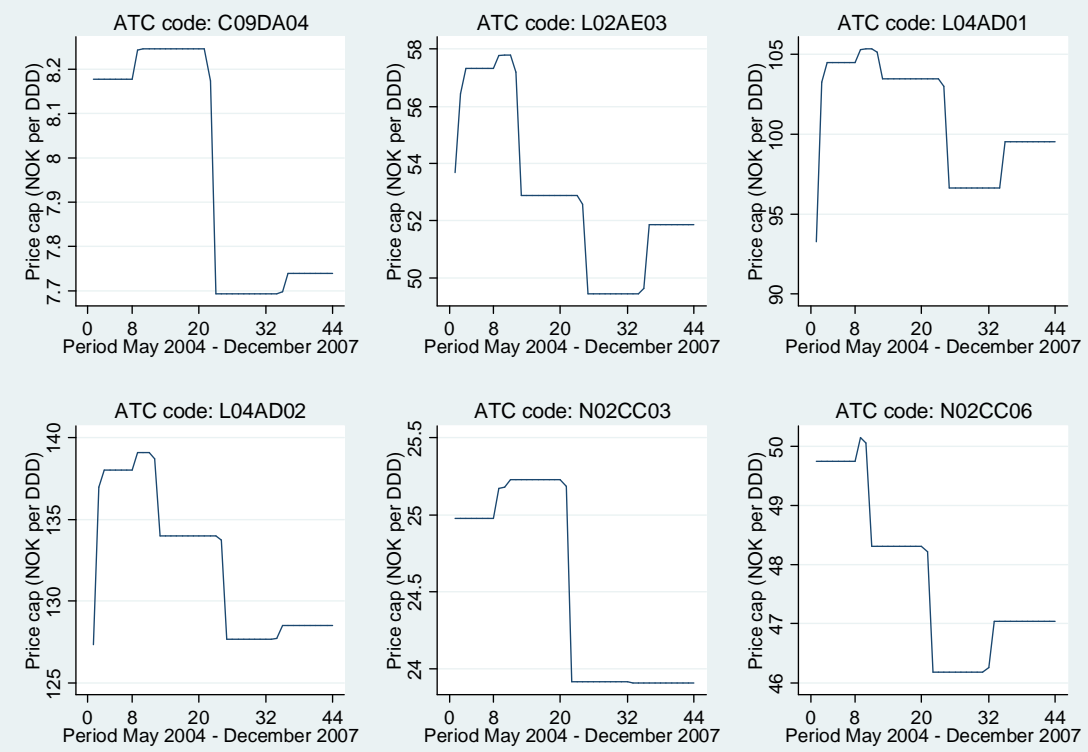
Table 1. Distribution of pharmacies according to chain, 2012.

\begin{tabular}{lllll}
\hline Pharmacy chain & Wholesaler & $\begin{array}{l}\text { Vertical } \\
\text { relation }\end{array}$ & $\begin{array}{l}\text { Number of } \\
\text { pharmacies }\end{array}$ & $\begin{array}{l}\text { Market share (no. } \\
\text { of pharmacies) }\end{array}$ \\
\hline Boots/Alliance apotek & Alliance Healthcare & Integrated & 147 & 20.0 \\
Apotek 1 & Apokjeden & Integrated & 282 & 38.2 \\
Vitusapotek & NMD & Integrated & 191 & 25.9 \\
Sykehusapotek & NMD & Contract & 32 & 4.3 \\
Ditt apotek & NMD & Franchise & 65 & 8.8 \\
Independent & Alliance Healthcare & Contract & 21 & 2.8 \\
\hline Total & & & 738 & 100.0 \\
\hline
\end{tabular}

Table 2. Mean prices and sales per month

\begin{tabular}{llll}
\hline & $\begin{array}{l}\text { Brand Name } \\
\text { without parallel } \\
\text { import }\end{array}$ & $\begin{array}{l}\text { Brand Name with } \\
\text { parallel import }\end{array}$ & Parallel import \\
\hline Price Cap & $71.78(210.68)$ & $53.43(69.28)$ & $42.14(45.75)$ \\
Retail Price & $71.62(210.39)$ & $53.34(69.24)$ & $41.61(45.18)$ \\
Producer Price & $49.84(153.40)$ & $36.45(49.12)$ & $26.36(29.13)$ \\
Sales per pack (in 1000 ddd) & $108.90(630.67)$ & $116.32(897.31)$ & $56.66(143.56)$ \\
\hline Number observations & 20197 & 11345 & 3610 \\
Number Packages & 548 & 258 & 186 \\
Number ATC-groups & 110 & 55 & 55 \\
\hline
\end{tabular}

Table 3. Comparing overall and within variation in the Price Cap Variable

\begin{tabular}{|c|c|c|c|c|c|c|}
\hline & \multicolumn{2}{|c|}{ The total sample } & \multicolumn{2}{|c|}{$\begin{array}{c}\text { Six largest substances } \\
\text { without parallel import }\end{array}$} & \multicolumn{2}{|c|}{$\begin{array}{c}\text { Six largest substances with } \\
\text { parallel import }\end{array}$} \\
\hline & Mean & $\begin{array}{l}\text { Standard } \\
\text { deviation }\end{array}$ & Mean & $\begin{array}{l}\text { Standard } \\
\text { deviation }\end{array}$ & Mean & $\begin{array}{l}\text { Standard } \\
\text { deviation }\end{array}$ \\
\hline Overall & 62.81 & 165.48 & 115.39 & 117.45 & 69.41 & 41.51 \\
\hline Between & & 162.79 & & 124.05 & & 43.50 \\
\hline Within & & 14.11 & & 6.02 & & 3.33 \\
\hline
\end{tabular}

Table 4. Effect of Price Cap Regulation on Market Shares of Brand-Name drugs, fixed effect models (robust standard errors)

\begin{tabular}{lll}
\hline Dependent variable: Brand-name market share & All products & $\begin{array}{l}\text { Products with parallel } \\
\text { import }\end{array}$ \\
\hline Log $P_{\text {it }}$ & $-0.178^{* * *}$ & $-0.491^{* * *}$ \\
& $(0.012)$ & $(0.034)$ \\
Constant term & $1.473^{* * *}$ & $2.354^{* * *}$ \\
& $(0.037)$ & $(0.107)$ \\
\hline Period fixed effect & Yes & Yes \\
ATC fixed effect & Yes & Yes \\
R-squared & 0.032 & 0.088 \\
Number ATC & 165 & 55 \\
Number observations & 7038 & 2372 \\
\hline
\end{tabular}


Table 5. Effect of Price Cap on Sales (DDD), fixed effect models (robust standard errors)

\begin{tabular}{lllll}
\hline & \multicolumn{3}{c}{ Brand-name } & Parallel Import \\
\hline $\begin{array}{l}\text { Dependent variable: Log } \\
\text { Sales (DDD) }\end{array}$ & All products & $\begin{array}{l}\text { Products } \\
\text { without parallel } \\
\text { import }\end{array}$ & $\begin{array}{l}\text { Products with } \\
\text { parallel import }\end{array}$ & All PI products \\
\hline Log $\mathrm{P}_{\text {it }}$ & $-0.483^{* * *}$ & $-0.349^{* * *}$ & $-0.860^{* * *}$ & $2.178^{* * *}$ \\
Constant term & $(0.066)^{* *}$ & $(0.078)$ & $(0.131)^{* * *}$ & $(0.0 .402)$ \\
& $10.832^{* * *}$ & $10.251^{* * *}$ & $12.420^{* * *}$ & $2.829^{* *}$ \\
\hline Period fixed effect & Yes & Yes & $(0.432)$ & $(1.258)$ \\
Pack fixed effect & Yes & Yes & Yes & Yes \\
R-squared & 0.044 & 0.037 & 0.061 & Yes \\
Number ATC & 165 & 110 & 55 & 0.103 \\
Number packs & 861 & 548 & 313 & 55 \\
Number observations & 31542 & 20197 & 11345 & 186 \\
\hline
\end{tabular}

Table 6. Effect of Price Cap on Producer Prices, fixed effect models (robust standard errors)

\begin{tabular}{lcccc}
\hline & \multicolumn{3}{c}{ Brand-name } & Parallel Import \\
\hline $\begin{array}{l}\text { Dependent variable: } \\
\text { Log Producer Price }\end{array}$ & All products & $\begin{array}{l}\text { Products } \\
\text { without parallel } \\
\text { import }\end{array}$ & $\begin{array}{l}\text { Products with } \\
\text { parallel import }\end{array}$ & All products \\
\hline Log $\mathrm{P}_{\text {it }}$ & $1.265^{* * *}$ & $1.338^{* * *}$ & $1.078^{* * *}$ & $0.622^{* * *}$ \\
Constant term & $(0.005)$ & $(0.007)$ & $(0.009)$ & $(0.018)$ \\
& $-1.286^{* * *}$ & $-1.496^{* * *}$ & $-0.738^{* * *}$ & $0.711^{* * *}$ \\
\hline Period fixed effect & $(0.017)$ & $(0.021)$ & $(0.030)$ & $(0.055)$ \\
Pack fixed effect & Yes & Yes & Yes & Yes \\
R-squared & Yes & Yes & Yes & Yes \\
Number ATC & 0.665 & 0.667 & 0.679 & 0.048 \\
Number packs & 165 & 110 & 55 & 55 \\
Number observations & 861 & 548 & 313 & 186 \\
\hline
\end{tabular}

Table 7. Effect of Price Cap on Profit, fixed effect models (robust standard errors)

\begin{tabular}{lcccc}
\hline $\begin{array}{l}\text { Dependent variable: Log } \\
\text { Profit }\end{array}$ & All products & $\begin{array}{l}\text { Products } \\
\text { without parallel } \\
\text { import }\end{array}$ & $\begin{array}{l}\text { Products with } \\
\text { parallel import }\end{array}$ \\
\hline Log $\mathrm{P}_{\text {it }}$ & & $0.989^{* * *}$ & 0.218 & \\
& $0.782^{* * *}$ & $(0.078)$ & $(0.132)$ & $2.800^{* * *}$ \\
Constant term & $(0.067)$ & $-2.758^{* * *}$ & $1.570^{* * *}$ & $-7.974^{* * *}$ \\
& $-1.966^{* * *}$ & $(0.230)$ & $(0.507)$ & $(1.248)$ \\
\hline Period fixed effect & $(0.205)$ & Yes & Yes & Yes \\
Pack fixed effect & Yes & Yes & Yes & Yes \\
R-squared & Yes & 0.038 & 0.049 & 0.119 \\
Number ATC & 0.040 & 110 & 55 & 55 \\
Number packs & 165 & 548 & 313 & 186 \\
Number observations & 861 & 20197 & 11345 & 3610 \\
\hline
\end{tabular}


Table 8. Effect of Price Cap Regulation on Total Expenditures, fixed effect models (robust standard errors)

\begin{tabular}{lccc}
\hline $\begin{array}{l}\text { Dependent variable: Log total } \\
\text { expenditures }\end{array}$ & All products & $\begin{array}{c}\text { Products without } \\
\text { parallel import }\end{array}$ & $\begin{array}{c}\text { Products with } \\
\text { parallel import }\end{array}$ \\
\hline Log $\mathrm{P}_{\text {it }}$ & $0.596^{* * *}$ & $0.527^{* * *}$ & $0.697^{* * *}$ \\
& $(0.057)$ & $(0.077)$ & $(0.080)$ \\
Constant term & $1.497^{* * *}$ & $1.523^{* * *}$ & 1.524 \\
& $(0.171)$ & $(0.227)$ & $(0.251)$ \\
\hline Period fixed effect & Yes & Yes & Yes \\
ATC fixed effect & Yes & Yes & Yes \\
R-squared & 0.140 & 0.124 & 0.199 \\
Number ATC & 165 & 110 & 55 \\
Number observations & 7038 & 4666 & 2372 \\
\hline
\end{tabular}


Table A. Descriptive statistics, substances with parallel import

\begin{tabular}{|c|c|c|c|c|c|c|c|}
\hline Substance & $\begin{array}{l}\text { Retail } \\
\text { Price } \\
\text { Brand- } \\
\text { Name }\end{array}$ & $\begin{array}{l}\text { Producer } \\
\text { Price } \\
\text { Brand- } \\
\text { Name }\end{array}$ & $\begin{array}{l}\text { Price Cap } \\
\text { Brand- } \\
\text { Name }\end{array}$ & $\begin{array}{l}\text { Retail } \\
\text { Price } \\
\text { Parallel- } \\
\text { Import }\end{array}$ & $\begin{array}{l}\text { Producer } \\
\text { Price } \\
\text { Parallel- } \\
\text { Import }\end{array}$ & $\begin{array}{l}\text { Price Cap } \\
\text { Parallel- } \\
\text { Import }\end{array}$ & $\begin{array}{l}\text { Periods } \\
\text { with } \\
\text { Parallel- } \\
\text { Import }\end{array}$ \\
\hline $\mathrm{A} 02 \mathrm{BC} 05$ & $\begin{array}{l}19.06 \\
(16.17)\end{array}$ & $\begin{array}{l}12.54 \\
(11.62)\end{array}$ & $\begin{array}{l}19.12 \\
(16.37)\end{array}$ & $\begin{array}{c}13.87 \\
(3.15)\end{array}$ & $\begin{array}{l}9.23 \\
(2.10)\end{array}$ & $\begin{array}{l}13.98 \\
(3.19)\end{array}$ & 44 \\
\hline A07AA02 & $\begin{array}{l}34.80 \\
(0.11)\end{array}$ & $\begin{array}{l}21.76 \\
(0.01)\end{array}$ & $\begin{array}{l}34.80 \\
(0.11)\end{array}$ & $\begin{array}{l}33.53 \\
(1.52)\end{array}$ & $\begin{array}{l}13.43 \\
(2.75)\end{array}$ & $\begin{array}{l}34.73 \\
(0.25)\end{array}$ & 44 \\
\hline A07EA06 & $\begin{array}{l}56.40 \\
(15.27)\end{array}$ & $\begin{array}{l}39.09 \\
(10.41)\end{array}$ & $\begin{array}{l}56.42 \\
(15.28)\end{array}$ & $\begin{array}{l}45.32 \\
(9.03)\end{array}$ & $\begin{array}{l}29.46 \\
(5.32)\end{array}$ & $\begin{array}{l}45.56 \\
(9.05)\end{array}$ & 21 \\
\hline A08AA10 & $\begin{array}{l}18.06 \\
(3.67)\end{array}$ & $\begin{array}{l}12.11 \\
(3.01)\end{array}$ & $\begin{array}{l}18.07 \\
(3.65)\end{array}$ & $\begin{array}{l}16.68 \\
(3.62)\end{array}$ & $\begin{array}{l}10.14 \\
(2.29)\end{array}$ & $\begin{array}{l}16.92 \\
(3.56)\end{array}$ & 10 \\
\hline A08AB01 & $\begin{array}{l}23.08 \\
(0.58)\end{array}$ & $\begin{array}{l}15.78 \\
(0.41)\end{array}$ & $\begin{array}{l}23.08 \\
(0.58)\end{array}$ & $\begin{array}{l}23.08 \\
(0.05)\end{array}$ & $\begin{array}{l}14.91 \\
(0.01)\end{array}$ & $\begin{array}{l}23.23 \\
(0.00)\end{array}$ & 5 \\
\hline A08AX01 & $\begin{array}{l}30.64 \\
(0.45) \\
\end{array}$ & $\begin{array}{l}21.51 \\
(0.23)\end{array}$ & $\begin{array}{l}30.64 \\
(0.45)\end{array}$ & $\begin{array}{l}30.80 \\
(0.02)\end{array}$ & $\begin{array}{l}20.79 \\
(0.01)\end{array}$ & $\begin{array}{l}31.08 \\
(0.00)\end{array}$ & 6 \\
\hline B01AC07 & $\begin{array}{l}5.15 \\
(0.38)\end{array}$ & $\begin{array}{l}2.62 \\
(0.31)\end{array}$ & $\begin{array}{l}5.18 \\
(0.42)\end{array}$ & $\begin{array}{l}5.25 \\
(0.41)\end{array}$ & $\begin{array}{l}2.38 \\
(0.24)\end{array}$ & $\begin{array}{l}5.36 \\
(0.45)\end{array}$ & 44 \\
\hline C09CA04 & $\begin{array}{l}6.86 \\
(1.51)\end{array}$ & $\begin{array}{l}4.47 \\
(0.91)\end{array}$ & $\begin{array}{l}6.86 \\
(1.51)\end{array}$ & $\begin{array}{l}5.86 \\
(1.21)\end{array}$ & $\begin{array}{l}3.92 \\
(0.70)\end{array}$ & $\begin{array}{l}5.86 \\
(1.21)\end{array}$ & 29 \\
\hline C09CA06 & $\begin{array}{l}6.35 \\
(3.05)\end{array}$ & $\begin{array}{l}4.03 \\
(1.79)\end{array}$ & $\begin{array}{l}6.35 \\
(3.05)\end{array}$ & $\begin{array}{l}4.83 \\
(1.20)\end{array}$ & $\begin{array}{l}3.16 \\
(0.74)\end{array}$ & $\begin{array}{l}4.85 \\
(1.20)\end{array}$ & 17 \\
\hline C09CA07 & $\begin{array}{l}6.93 \\
(2.55)\end{array}$ & $\begin{array}{l}4.25 \\
(1.33)\end{array}$ & $\begin{array}{l}6.93 \\
(2.55)\end{array}$ & $\begin{array}{l}5.20 \\
(1.32)\end{array}$ & $\begin{array}{l}2.50 \\
(0.83)\end{array}$ & $\begin{array}{l}5.26 \\
(1.32)\end{array}$ & 25 \\
\hline C09DA01 & $\begin{array}{l}9.04 \\
(1.62)\end{array}$ & $\begin{array}{l}6.09 \\
(1.12)\end{array}$ & $\begin{array}{l}9.04 \\
(1.62)\end{array}$ & $\begin{array}{l}9.87 \\
(0.18)\end{array}$ & $\begin{array}{l}5.87 \\
(0.01)\end{array}$ & $\begin{array}{l}9.89 \\
(0.16)\end{array}$ & 21 \\
\hline C09DA03 & $\begin{array}{l}8.85 \\
(1.06)\end{array}$ & $\begin{array}{l}5.92 \\
(0.69)\end{array}$ & $\begin{array}{l}8.86 \\
(1.06)\end{array}$ & $\begin{array}{l}9.06 \\
(0.23)\end{array}$ & $\begin{array}{l}5.54 \\
(0.07)\end{array}$ & $\begin{array}{l}9.17 \\
(0.20)\end{array}$ & 8 \\
\hline C09DA04 & $\begin{array}{l}10.06 \\
(1.58)\end{array}$ & $\begin{array}{l}6.60 \\
(1.12)\end{array}$ & $\begin{array}{l}10.07 \\
(1.57)\end{array}$ & $\begin{array}{l}8.98 \\
(1.18)\end{array}$ & $\begin{array}{l}5.79 \\
(0.84)\end{array}$ & $\begin{array}{l}8.99 \\
(1.19)\end{array}$ & 44 \\
\hline C10AA04 & $\begin{array}{l}6.27 \\
(2.21)\end{array}$ & $\begin{array}{l}4.23 \\
(1.52)\end{array}$ & $\begin{array}{l}6.27 \\
(2.21)\end{array}$ & $\begin{array}{l}4.79 \\
(1.20)\end{array}$ & $\begin{array}{l}2.59 \\
(0.34)\end{array}$ & $\begin{array}{l}4.81 \\
(1.21)\end{array}$ & 19 \\
\hline C10AX06 & $\begin{array}{l}34.53 \\
(1.18)\end{array}$ & $\begin{array}{l}21.33 \\
(2.14)\end{array}$ & $\begin{array}{l}34.55 \\
(1.19)\end{array}$ & $\begin{array}{l}33.39 \\
(0.58)\end{array}$ & $\begin{array}{l}22.22 \\
(0.00)\end{array}$ & $\begin{array}{l}33.57 \\
(0.10)\end{array}$ & 15 \\
\hline G03DA04 & $\begin{array}{l}41.49 \\
(5.23)\end{array}$ & $\begin{array}{l}28.74 \\
(3.91)\end{array}$ & $\begin{array}{l}41.49 \\
(5.23)\end{array}$ & $\begin{array}{l}36.52 \\
(0.18)\end{array}$ & $\begin{array}{l}23.67 \\
(0.00)\end{array}$ & $\begin{array}{l}37.58 \\
(0.10)\end{array}$ & 15 \\
\hline G04CB01 & $\begin{array}{l}9.91 \\
(2.24)\end{array}$ & $\begin{array}{l}6.07 \\
(2.54)\end{array}$ & $\begin{array}{l}10.27 \\
(1.84)\end{array}$ & $\begin{array}{l}10.80 \\
(1.58)\end{array}$ & $\begin{array}{l}6.92 \\
(1.01)\end{array}$ & $\begin{array}{l}10.88 \\
(1.52)\end{array}$ & 44 \\
\hline G04CB02 & $\begin{array}{l}11.01 \\
(1.09)\end{array}$ & $\begin{array}{l}6.98 \\
(0.69)\end{array}$ & $\begin{array}{l}11.01 \\
(1.08)\end{array}$ & $\begin{array}{l}11.01 \\
(0.53)\end{array}$ & $\begin{array}{l}6.53 \\
(0.03)\end{array}$ & $\begin{array}{l}11.04 \\
(0.48)\end{array}$ & 23 \\
\hline H01AC01 & $\begin{array}{l}233.50 \\
(16.03)\end{array}$ & $\begin{array}{l}168.10 \\
(11.19)\end{array}$ & $\begin{array}{l}233.57 \\
(16.04)\end{array}$ & $\begin{array}{l}225.04 \\
(6.44)\end{array}$ & $\begin{array}{l}148.25 \\
(3.52)\end{array}$ & $\begin{array}{l}228.83 \\
(6.44)\end{array}$ & 18 \\
\hline H01CA02 & $\begin{array}{l}37.55 \\
(0.12)\end{array}$ & $\begin{array}{l}25.85 \\
(0.07)\end{array}$ & $\begin{array}{l}37.55 \\
(0.12)\end{array}$ & $\begin{array}{l}37.37 \\
(0.13)\end{array}$ & $\begin{array}{l}26.32 \\
(0.24)\end{array}$ & $\begin{array}{l}37.37 \\
(0.13)\end{array}$ & 9 \\
\hline J05AB11 & $\begin{array}{l}168.41 \\
(9.61)\end{array}$ & $\begin{array}{l}108.20 \\
(8.29)\end{array}$ & $\begin{array}{l}169.38 \\
(9.62)\end{array}$ & $\begin{array}{l}170.82 \\
(6.93)\end{array}$ & $\begin{array}{l}111.11 \\
(4.88)\end{array}$ & $\begin{array}{l}171.35 \\
(6.82)\end{array}$ & 31 \\
\hline L02AE03 & $\begin{array}{l}51.25 \\
(3.62)\end{array}$ & $\begin{array}{l}36.62 \\
(2.57)\end{array}$ & $\begin{array}{l}51.28 \\
(3.63)\end{array}$ & $\begin{array}{l}51.67 \\
(3.49) \\
\end{array}$ & $\begin{array}{l}35.56 \\
(2.09)\end{array}$ & $\begin{array}{l}52.12 \\
(3.43)\end{array}$ & 44 \\
\hline L02BG03 & $\begin{array}{l}39.33 \\
(2.13)\end{array}$ & $\begin{array}{l}27.92 \\
(1.34)\end{array}$ & $\begin{array}{l}39.36 \\
(2.12)\end{array}$ & $\begin{array}{l}38.48 \\
(1.96)\end{array}$ & $\begin{array}{l}27.45 \\
(1.67)\end{array}$ & $\begin{array}{l}38.92 \\
(2.02)\end{array}$ & 34 \\
\hline L04AD01 & $\begin{array}{l}104.68 \\
(14.98)\end{array}$ & $\begin{array}{l}68.27 \\
(13.75)\end{array}$ & $\begin{array}{l}104.76 \\
(14.97)\end{array}$ & $\begin{array}{l}107.66 \\
(8.38)\end{array}$ & $\begin{array}{l}64.29 \\
(10.00)\end{array}$ & $\begin{array}{l}109.95 \\
(8.46)\end{array}$ & 44 \\
\hline L04AD02 & $\begin{array}{l}145.76 \\
(32.47)\end{array}$ & $\begin{array}{l}102.79 \\
(21.82)\end{array}$ & $\begin{array}{l}145.78 \\
(32.46)\end{array}$ & $\begin{array}{l}124.28 \\
(10.52)\end{array}$ & $\begin{array}{l}84.53 \\
(8.21)\end{array}$ & $\begin{array}{l}125.42 \\
(10.48)\end{array}$ & 44 \\
\hline $\mathrm{N} 02 \mathrm{CC} 03$ & $\begin{array}{l}49.57 \\
(9.66)\end{array}$ & $\begin{array}{l}31.89 \\
(4.70)\end{array}$ & $\begin{array}{l}49.62 \\
(9.69)\end{array}$ & $\begin{array}{l}44.45 \\
(13.24)\end{array}$ & $\begin{array}{l}28.12 \\
(7.73)\end{array}$ & $\begin{array}{l}44.72 \\
(13.13)\end{array}$ & 44 \\
\hline
\end{tabular}




\begin{tabular}{|c|c|c|c|c|c|c|c|}
\hline Substance & $\begin{array}{l}\text { Retail } \\
\text { Price } \\
\text { Brand- } \\
\text { Name }\end{array}$ & $\begin{array}{l}\text { Producer } \\
\text { Price } \\
\text { Brand- } \\
\text { Name }\end{array}$ & $\begin{array}{l}\text { Price Cap } \\
\text { Brand- } \\
\text { Name }\end{array}$ & $\begin{array}{l}\text { Retail } \\
\text { Price } \\
\text { Parallel- } \\
\text { Import }\end{array}$ & $\begin{array}{l}\text { Producer } \\
\text { Price } \\
\text { Parallel- } \\
\text { Import }\end{array}$ & $\begin{array}{l}\text { Price Cap } \\
\text { Parallel- } \\
\text { Import }\end{array}$ & $\begin{array}{l}\text { Periods } \\
\text { with } \\
\text { Parallel } \\
\text { Import }\end{array}$ \\
\hline N02CC05 & $\begin{array}{l}56.74 \\
(3.42)\end{array}$ & $\begin{array}{l}34.26 \\
(2.38)\end{array}$ & $\begin{array}{l}56.75 \\
(3.40)\end{array}$ & $\begin{array}{l}52.16 \\
(0.80)\end{array}$ & $\begin{array}{l}30.69 \\
(0.14)\end{array}$ & $\begin{array}{l}53.25 \\
(0.96)\end{array}$ & 19 \\
\hline N02CC06 & $\begin{array}{l}65.79 \\
(22.92)\end{array}$ & $\begin{array}{l}42.67 \\
(14.76)\end{array}$ & $\begin{array}{l}65.84 \\
(22.95)\end{array}$ & $\begin{array}{l}46.75 \\
(1.28)\end{array}$ & $\begin{array}{l}31.36 \\
(0.90)\end{array}$ & $\begin{array}{l}47.38 \\
(1.29)\end{array}$ & 44 \\
\hline N03AE01 & $\begin{array}{l}8.23 \\
(3.14)\end{array}$ & $\begin{array}{l}3.63 \\
(1.23)\end{array}$ & $\begin{array}{l}8.23 \\
(3.14)\end{array}$ & $\begin{array}{l}7.76 \\
(3.13)\end{array}$ & $\begin{array}{l}3.26 \\
(0.14)\end{array}$ & $\begin{array}{l}7.86 \\
(3.12)\end{array}$ & 44 \\
\hline N03AX14 & $\begin{array}{l}39.45 \\
(3.65)\end{array}$ & $\begin{array}{l}27.40 \\
(1.87)\end{array}$ & $\begin{array}{l}39.46 \\
(3.65)\end{array}$ & $\begin{array}{l}37.52 \\
(0.74)\end{array}$ & $\begin{array}{l}26.46 \\
(0.14)\end{array}$ & $\begin{array}{l}37.79 \\
(0.85)\end{array}$ & 4 \\
\hline N03AX16 & $\begin{array}{l}33.76 \\
(10.41)\end{array}$ & $\begin{array}{l}21.85 \\
(5.85)\end{array}$ & $\begin{array}{l}33.76 \\
(10.40)\end{array}$ & $\begin{array}{l}18.67 \\
(0.91)\end{array}$ & $\begin{array}{l}12.76 \\
(0.46)\end{array}$ & $\begin{array}{l}18.73 \\
(0.92)\end{array}$ & 21 \\
\hline N04BA02 & $\begin{array}{l}31.19 \\
(76.90)\end{array}$ & $\begin{array}{l}20.79 \\
(56.42)\end{array}$ & $\begin{array}{l}31.21 \\
(76.92)\end{array}$ & $\begin{array}{l}8.28 \\
(1.87)\end{array}$ & $\begin{array}{l}4.74 \\
(1.09)\end{array}$ & $\begin{array}{l}8.38 \\
(1.89)\end{array}$ & 44 \\
\hline N04BA03 & $\begin{array}{l}68.09 \\
(31.25)\end{array}$ & $\begin{array}{l}44.06 \\
(20.52)\end{array}$ & $\begin{array}{l}68.12 \\
(31.26)\end{array}$ & $\begin{array}{l}66.19 \\
(30.21)\end{array}$ & $\begin{array}{l}40.36 \\
(16.53)\end{array}$ & $\begin{array}{l}66.36 \\
(30.12)\end{array}$ & 21 \\
\hline N04BC05 & $\begin{array}{l}67.89 \\
(11.51)\end{array}$ & $\begin{array}{l}41.47 \\
(3.85)\end{array}$ & $\begin{array}{l}67.89 \\
(11.52)\end{array}$ & $\begin{array}{l}58.91 \\
(0.26)\end{array}$ & $\begin{array}{l}35.00 \\
(0.00)\end{array}$ & $\begin{array}{l}58.91 \\
(0.26)\end{array}$ & 7 \\
\hline N05AE04 & $\begin{array}{l}62.54 \\
(73.21)\end{array}$ & $\begin{array}{l}43.13 \\
(46.11)\end{array}$ & $\begin{array}{l}62.54 \\
(73.21)\end{array}$ & $\begin{array}{l}49.00 \\
(12.40)\end{array}$ & $\begin{array}{l}31.57 \\
(8.80)\end{array}$ & $\begin{array}{l}49.43 \\
(13.00)\end{array}$ & 28 \\
\hline N05AH03 & $\begin{array}{l}48.25 \\
(9.90)\end{array}$ & $\begin{array}{l}33.46 \\
(5.25)\end{array}$ & $\begin{array}{l}48.25 \\
(9.90)\end{array}$ & $\begin{array}{l}41.67 \\
(1.16)\end{array}$ & $\begin{array}{l}27.85 \\
(3.74)\end{array}$ & $\begin{array}{l}42.62 \\
(0.67)\end{array}$ & 44 \\
\hline N05AH04 & $\begin{array}{l}56.92 \\
(21.90)\end{array}$ & $\begin{array}{l}36.71 \\
(14.51)\end{array}$ & $\begin{array}{l}58.73 \\
(21.50)\end{array}$ & $\begin{array}{l}39.18 \\
(1.08)\end{array}$ & $\begin{array}{l}26.69 \\
(0.33)\end{array}$ & $\begin{array}{l}39.28 \\
(0.95)\end{array}$ & 16 \\
\hline N05AX12 & $\begin{array}{l}72.59 \\
(36.24)\end{array}$ & $\begin{array}{l}51.04 \\
(25.18)\end{array}$ & $\begin{array}{l}72.59 \\
(36.24)\end{array}$ & $\begin{array}{l}50.86 \\
(11.72)\end{array}$ & $\begin{array}{l}34.89 \\
(8.06)\end{array}$ & $\begin{array}{l}51.42 \\
(11.88)\end{array}$ & 2 \\
\hline N06AA06 & $\begin{array}{l}12.78 \\
(6.28)\end{array}$ & $\begin{array}{l}6.06 \\
(3.53)\end{array}$ & $\begin{array}{l}13.06 \\
(6.06)\end{array}$ & $\begin{array}{l}7.33 \\
(0.80)\end{array}$ & $\begin{array}{l}3.31 \\
(0.79)\end{array}$ & $\begin{array}{l}7.91 \\
(0.75)\end{array}$ & 44 \\
\hline N06AB10 & $\begin{array}{l}7.77 \\
(1.31)\end{array}$ & $\begin{array}{l}4.94 \\
(0.61)\end{array}$ & $\begin{array}{l}7.79 \\
(1.31)\end{array}$ & $\begin{array}{l}6.27 \\
(0.07)\end{array}$ & $\begin{array}{l}3.89 \\
(0.15)\end{array}$ & $\begin{array}{l}6.37 \\
(0.02)\end{array}$ & 18 \\
\hline N06AX16 & $\begin{array}{l}13.90 \\
(3.43)\end{array}$ & $\begin{array}{l}8.63 \\
(1.47) \\
\end{array}$ & $\begin{array}{l}14.30 \\
(3.04)\end{array}$ & $\begin{array}{l}12.59 \\
(0.24) \\
\end{array}$ & $\begin{array}{l}8.35 \\
(0.01)\end{array}$ & $\begin{array}{l}12.76 \\
(0.01)\end{array}$ & 13 \\
\hline N06BA09 & $\begin{array}{l}138.16 \\
(80.35)\end{array}$ & $\begin{array}{l}92.37 \\
(53.15)\end{array}$ & $\begin{array}{l}138.38 \\
(80.48)\end{array}$ & $\begin{array}{l}124.84 \\
(75.88)\end{array}$ & $\begin{array}{l}85.19 \\
(51.60)\end{array}$ & $\begin{array}{l}126.20 \\
(76.54)\end{array}$ & 10 \\
\hline N06DA02 & $\begin{array}{l}35.38 \\
(10.27)\end{array}$ & $\begin{array}{l}25.02 \\
(7.41)\end{array}$ & $\begin{array}{l}35.42 \\
(10.27)\end{array}$ & $\begin{array}{l}33.96 \\
(9.99)\end{array}$ & $\begin{array}{l}22.08 \\
(6.90)\end{array}$ & $\begin{array}{l}34.13 \\
(10.02)\end{array}$ & 40 \\
\hline N06DA03 & $\begin{array}{l}48.83 \\
(24.45)\end{array}$ & $\begin{array}{l}33.68 \\
(16.66)\end{array}$ & $\begin{array}{l}48.88 \\
(24.50)\end{array}$ & $\begin{array}{l}85.41 \\
(0.22) \\
\end{array}$ & $\begin{array}{l}52.50 \\
(0.00)\end{array}$ & $\begin{array}{l}85.98 \\
(0.07)\end{array}$ & 23 \\
\hline N07BC01 & $\begin{array}{l}50.91 \\
(12.24)\end{array}$ & $\begin{array}{l}25.20 \\
(3.27)\end{array}$ & $\begin{array}{l}51.01 \\
(12.19)\end{array}$ & $\begin{array}{l}39.50 \\
(0.89)\end{array}$ & $\begin{array}{l}23.57 \\
(0.38)\end{array}$ & $\begin{array}{l}40.05 \\
(1.24)\end{array}$ & 5 \\
\hline R01AC02 & $\begin{array}{l}8.53 \\
(0.45)\end{array}$ & $\begin{array}{l}5.16 \\
(0.32)\end{array}$ & $\begin{array}{l}8.53 \\
(0.45)\end{array}$ & $\begin{array}{l}8.96 \\
(0.45)\end{array}$ & $\begin{array}{l}5.04 \\
(0.38)\end{array}$ & $\begin{array}{l}9.14 \\
(0.51)\end{array}$ & 37 \\
\hline R01AD05 & $\begin{array}{l}3.11 \\
(0.95)\end{array}$ & $\begin{array}{l}1.80 \\
(0.37)\end{array}$ & $\begin{array}{l}3.11 \\
(0.95)\end{array}$ & $\begin{array}{l}2.35 \\
(0.19) \\
\end{array}$ & $\begin{array}{l}1.33 \\
(0.12)\end{array}$ & $\begin{array}{l}2.39 \\
(0.19)\end{array}$ & 44 \\
\hline R01AD09 & $\begin{array}{l}4.12 \\
(0.29)\end{array}$ & $\begin{array}{l}2.45 \\
(0.09)\end{array}$ & $\begin{array}{l}4.13 \\
(0.29)\end{array}$ & $\begin{array}{l}4.36 \\
(0.07)\end{array}$ & $\begin{array}{l}1.30 \\
(0.00)\end{array}$ & $\begin{array}{l}4.36 \\
(0.07)\end{array}$ & 7 \\
\hline R03AC03 & $\begin{array}{l}7.53 \\
(5.50)\end{array}$ & $\begin{array}{l}4.57 \\
(3.47)\end{array}$ & $\begin{array}{l}7.53 \\
(5.50)\end{array}$ & $\begin{array}{l}2.84 \\
(0.06)\end{array}$ & $\begin{array}{l}1.24 \\
(0.09)\end{array}$ & $\begin{array}{l}2.88 \\
(0.06)\end{array}$ & 36 \\
\hline R03AK06 & $\begin{array}{l}16.07 \\
(3.67)\end{array}$ & $\begin{array}{l}10.91 \\
(2.62)\end{array}$ & $\begin{array}{l}16.09 \\
(3.67)\end{array}$ & $\begin{array}{l}15.31 \\
(0.39)\end{array}$ & $\begin{array}{l}10.17 \\
(0.41)\end{array}$ & $\begin{array}{l}15.78 \\
(0.00)\end{array}$ & 4 \\
\hline R03AK07 & $\begin{array}{l}17.45 \\
(0.73)\end{array}$ & $\begin{array}{l}12.07 \\
(0.50)\end{array}$ & $\begin{array}{l}17.45 \\
(0.73)\end{array}$ & $\begin{array}{l}18.07 \\
(0.51)\end{array}$ & $\begin{array}{l}12.47 \\
(0.39)\end{array}$ & $\begin{array}{l}18.11 \\
(0.51)\end{array}$ & 27 \\
\hline R03BB01 & $\begin{array}{l}5.01 \\
(1.55)\end{array}$ & $\begin{array}{l}2.88 \\
(1.13)\end{array}$ & $\begin{array}{l}5.01 \\
(1.55)\end{array}$ & $\begin{array}{l}3.11 \\
(0.47)\end{array}$ & $\begin{array}{l}1.79 \\
(0.46)\end{array}$ & $\begin{array}{l}3.41 \\
(0.46)\end{array}$ & 19 \\
\hline R06AX27 & $\begin{array}{l}5.49 \\
(1.43)\end{array}$ & $\begin{array}{l}2.76 \\
(0.49)\end{array}$ & $\begin{array}{l}5.49 \\
(1.43)\end{array}$ & $\begin{array}{l}4.02 \\
(0.33)\end{array}$ & $\begin{array}{l}2.44 \\
(0.06)\end{array}$ & $\begin{array}{l}4.03 \\
(0.33)\end{array}$ & 21 \\
\hline
\end{tabular}




\begin{tabular}{|l|l|l|l|l|l|l|l|}
\hline Substance & $\begin{array}{l}\text { Retail } \\
\text { Price } \\
\text { Brand- } \\
\text { Name }\end{array}$ & $\begin{array}{l}\text { Producer } \\
\text { Price } \\
\text { Brand- } \\
\text { Name }\end{array}$ & $\begin{array}{l}\text { Price Cap } \\
\text { Brand- } \\
\text { Name }\end{array}$ & $\begin{array}{l}\text { Retail } \\
\text { Price } \\
\text { Parallel- } \\
\text { Import }\end{array}$ & $\begin{array}{l}\text { Producer } \\
\text { Price } \\
\text { Parallel- } \\
\text { Import }\end{array}$ & $\begin{array}{l}\text { Price Cap } \\
\text { Parallel- } \\
\text { Import }\end{array}$ & $\begin{array}{l}\text { Periods } \\
\text { with } \\
\text { Parallel- } \\
\text { Import }\end{array}$ \\
\hline S01EE01 & 7.75 & 4.97 & 7.75 & 7.49 & 4.87 & 7.63 & 9 \\
& $(0.48)$ & $(0.17)$ & $(0.48)$ & $(0.03)$ & $(0.02)$ & $0.03)$ & \\
\hline V03AE02 & 91.86 & 65.25 & 91.87 & 91.64 & 62.23 & 92.07 & 34 \\
& $(4.51)$ & $(2.46)$ & $(4.52)$ & $(4.66)$ & $(1.49)$ & $(4.60)$ & \\
\hline
\end{tabular}




\section{Most Recent Working Paper}

NIPE WP $\quad$ Brekke, Kurt R., Holmäs, Tor Helge e Straume, Odd Rune, "Price Regulation and Parallel

01/2014 Imports of Pharmaceuticals", 2014

NIPE WP Leal, Cristiana Cerqueira, Armada, Manuel Rocha e Loureiro, Gilberto , "Individual

22/2013 Investors Repurchasing Behavior: Preference for Stocks Previously Owned", 2013

NIPE WP Loureiro, Gilberto e Alvaro G. Taboada, "Equity Offerings Abroad and the adoption of IFRS: A

21/2013 test of the Capital Markets Liability of Foreignness", 2013

NIPE WP Loureiro, Gilberto e Alvaro G. Taboada, "Do Improvements in the Information Environment

20/2013 Affect Real Investment Decisions?”, 2013

NIPE WP Bogas, Patrícia e Natália Barbosa, "High-Growth Firms: What is the Impact of Region-Specific

19/2013 Characteristics?", 2013

NIPE WP Portela, Miguel e Paul Schweinzer, “The Parental Co-Immunization Hypothesis”, 2013

$18 / 2013$

NIPE WP Martins, Susana e Francisco José Veiga, "Government size, composition of public expenditure,

17/2013 and economic development", 2013

NIPE WP Bastos, Paulo e Odd Rune Straume, "Preschool education in Brazil: Does public supply crowd

$16 / 2013$

NIPE WP Martins, Rodrigo e Francisco José Veiga, "Does voter turnout affect the votes for the incumbent

15/2013 government?", 2013

NIPE WP Aguiar-Conraria, Luís, Pedro C. Magalhães e Christoph A. Vanberg, "Experimental evidence

$14 / 2013$ that quorum rules discourage turnout and promote election boycotts", 2013

NIPE WP Silva, José Ferreira, J. Cadima Ribeiro, “As Assimetrias Regionais em Portugal: análise da

13/2013 convergência versus divergência ao nível dos municípios”, 2013

NIPE WP Faria, Ana Paula, Natália Barbosa e Vasco Eiriz, "Firms' innovation across regions: an

12/2013 exploratory study", 2013

NIPE WP Veiga, Francisco José, "Instituições, Estabilidade Política e Desempenho Económico

11/2013 Implicações para Portugal”, 2013

NIPE WP Barbosa, Natália, Ana Paula Faria e Vasco Eiriz, "Industry- and firm-specific factors of

10/2013 innovation novelty", 2013

NIPE WP Castro, Vítor e Megumi Kubota, "Duration dependence and change-points in the likelihood of

09/2013

NIPE WP

08/2013

NIPE WP

07/2013

credit booms ending", 2013

NIPE WP

06/2013

Monteiro, Natália Pimenta e Geoff Stewart "Scale, Scope and Survival: A Comparison of

Cooperative and Capitalist Modes of Production", 2013

NIPE WP

05/2013

NIPE WP

$04 / 2013$

Esteves, Rosa-Branca e Joana Resende, "Competitive Targeted Advertising with Price

Discrimination", 2013

NIPE WP

03/2013

NIPE WP

$02 / 2013$

NIPE WP

$01 / 2013$

NIPE WP

$27 / 2012$

NIPE WP

26/2012

Barbosa, Natália, Maria Helena Guimarães e Ana Paula Faria, "Single Market non-

compliance: how relevant is the institutional setting?", 2013

Lommerud, Kjell Erik, Odd Rune Straume e Steinar Vagstad, "Mommy tracks and public

policy: On self-fulfilling prophecies and gender gaps in promotion", 2013

Brekke, Kurt R., Luigi Siciliani e Odd Rune Straume, "Hospital Mergers: A Spatial

Competition Approach", 2013

Faria, Ana Paula e Natália Barbosa, “Does venture capital really foster innovation?”, 2013

NIPE WP

$25 / 2012$

Esteves, Rosa Branca, “Customer Poaching with Retention Strategies”, 2013

Aguiar-Conraria, Luís, Teresa Maria Rodrigues e Maria Joana Soares, "Oil Shocks and the Euro as an Optimum Currency Area”, 2013

Ricardo M. Sousa, "The Effects of Monetary Policy in a Small Open Economy: The Case of Portugal" 2012

Sushanta K. Mallick e Ricardo M. Sousa, "Is Technology Factor-Neutral? Evidence from the US Manufacturing Sector" 2012

Jawadi, F. e Ricardo M. Sousa, "Structural Breaks and Nonlinearity in US and UK Public Debt" 2012 